\title{
Heavy metal poisoning and its laboratory investigation
}

\author{
Dianne R Baldwin and William J Marshall \\ From the Department of Clinical Biochemistry, King's College Hospital, London SE5 9RS, UK
}

\begin{abstract}
Additional key phrases: cadmium; lead; mercury; thallium; bismuth; arsenic; tin; antimony
\end{abstract}

\section{INTRODUCTION AND OVERVIEW}

The term 'heavy metal' is, in this context, imprecise. It should probably be reserved for those elements with an atomic mass of 200 or greater [e.g., mercury (200), thallium (204), lead (207), bismuth (209) and the thorium series]. In practice, the term has come to embrace any metal, exposure to which is clinically undesirable and which constitutes a potential hazard. Our intention in this review is to provide an overview of some general concepts of metal toxicology and to discuss in detail metals of particular importance, namely, cadmium, lead, mercury, thallium, bismuth, arsenic, antimony and tin.

Poisoning from individual metals is rare in the UK, even when there is a known risk of exposure. Table 1 shows that during 1991-92 only $1.1 \%$ of male lead workers in the UK and $5.5 \%$ of female workers exceeded the legal limits for blood lead concentration. ${ }^{1}$ Collectively, however, poisoning with metals forms an important aspect of toxicology because of their widespread use and availability. Furthermore, hitherto unrecognized hazards and accidents continue to be described.

The investigation of metal poisoning forms a distinct specialist area, since most metals are usually measured using atomic absorption techniques. Analyses require considerable expertise and meticulous attention to detail to ensure valid results. ${ }^{2}$ Different analytical performance standards may be required of assays used for environmental and occupational

Dianne Baldwin died on 24 November 1998. This article is dedicated to her memory.

This review was commissioned by the Clinical Laboratory Investigations Standing Committee of the Association of Clinical Biochemists but does not necessarily reflect their views.

Correspondence: Dr William Marshall.

E-mail: william.marshall@kcl.ac.uk monitoring, or for solely toxicological purposes. Because of the high capital cost of good quality instruments, the relatively small numbers of tests required and the variety of metals, it is more cost-effective if such testing is carried out in regional, national or other centres having the necessary experience. Nevertheless, patients are frequently cared for locally, and clinical biochemists play a crucial role in maintaining a high index of suspicion and liaising with clinical colleagues to ensure the provision of correct samples for analysis and timely advice.

\section{EXPOSURE AND TOXICITY}

Potentially, toxic exposure to heavy metals arises in diverse circumstances, including environmental, therapeutic and industrial, by accident, and by harmful intent. There is a spectrum of exposure patterns from chronic, low levels, such as occur among children exposed to lead paint in older houses, to acute, high-dose exposure, either intentionally or by accident. Accidental exposure may be small-scale, as in the case of a child who swallows a mercury battery, or large-scale, as with the contamination of a water supply with aluminium sulphate (alum) at Camelford. ${ }^{3}$

Appreciation of the toxicokinetics of individual metals is important for an understanding of the rationale of monitoring and treatment. Relevant concepts fall into two categories. Exposure is the amount of a particular physical or chemical agent that reaches the target; ${ }^{4}$ biological monitoring (BM) of exposure concerns the level and form of the element in the environment and in the body. Effective BM requires an accurate measure of the internal dose, which is the amount or concentration of a given chemical at the site of effect, and may refer to the overall body burden or to that in a particular compartment. Internal dose is usually assessed by some convenient and robust biochemical measurement which shows good correlation with the body burden, since in vivo measurement is seldom practicable. Table 2 


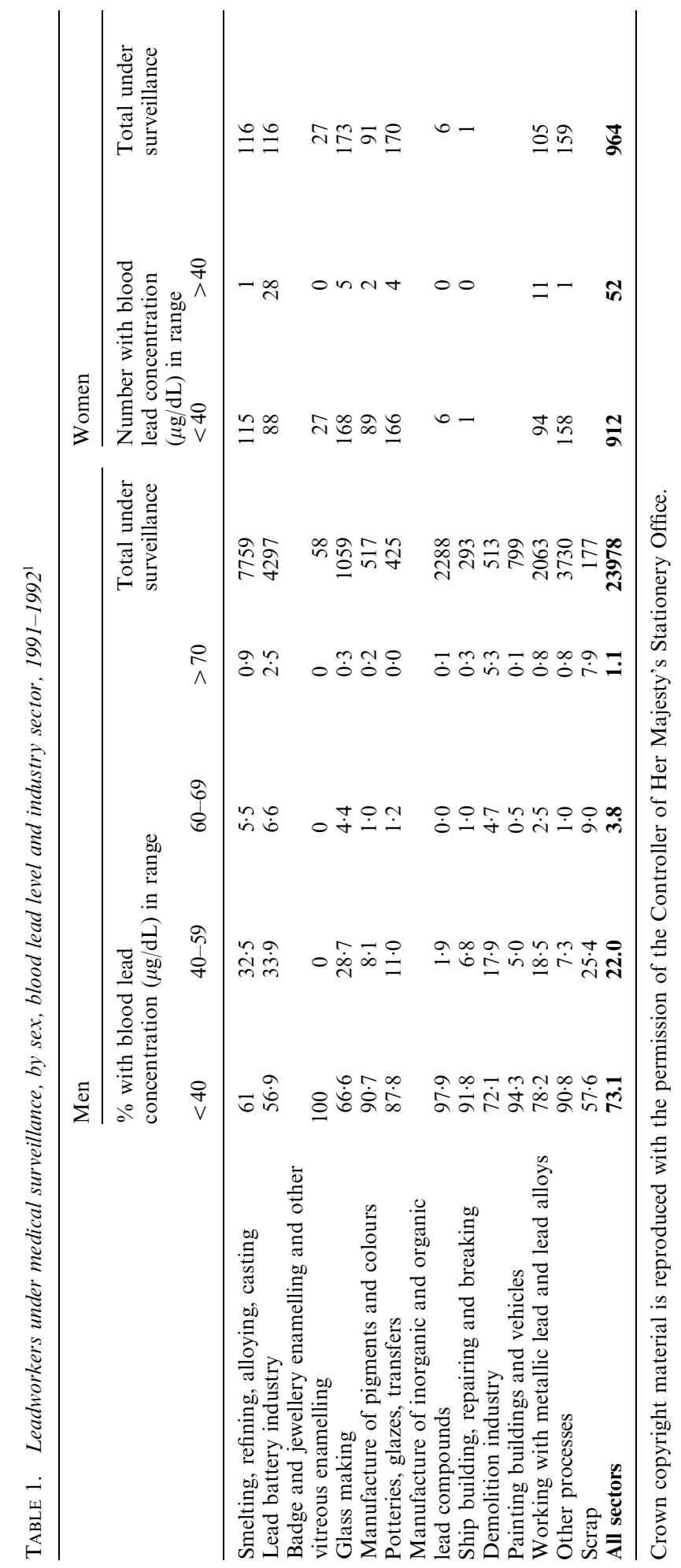


TABLE 2. Factors affecting the exposure of individuals to toxic metals

\begin{tabular}{|c|c|}
\hline Element & $\begin{array}{l}\text { Atomic radius, valency, mobility, } \\
\text { hydration }\end{array}$ \\
\hline Chemical form & Organic, inorganic, oxidation state \\
\hline Compound & Sulphide, oxide, salts \\
\hline Physical form & $\begin{array}{l}\text { Dust (particle size), fume, } \\
\text { solubility }\end{array}$ \\
\hline Concentration & High, low, seasonality \\
\hline Duration & Acute, chronic, variable \\
\hline Interactions & $\begin{array}{l}\text { With other metals, with } \\
\text { compounds (bioavailability) }\end{array}$ \\
\hline Route of entry & Oral, inhalation, skin \\
\hline Geography & $\begin{array}{l}\text { Wind direction, water run-off, } \\
\text { distance from source (especially } \\
\text { industrial), transport (by man) }\end{array}$ \\
\hline Foodchains & Plant uptake, agriculture, fishing \\
\hline
\end{tabular}

shows some of the factors which may influence exposure.

The second concept relates to the biological effects of exposure (BEM). Assessment of these presents more problems, since individuals may differ markedly in their responses to similar exposure. Both toxic and essential substances exhibit a continuum of effects over a range of concentration. Figure 1 uses lead and its adverse effects as an example of a toxic agent, ${ }^{5}$ and zinc as an example of an essential substance which has adverse effects only at extremes of concentration. The critical organ is the first organ in which adverse effects, reversible or irreversible, occur under the particular circumstances, e.g., the kidney in chronic cadmium exposure; the critical effect is the first physiological or biochemical change which can be detected, ${ }^{6}$ e.g., altered haem synthesis in lead poisoning. Both may vary according to the nature and route of exposure to the metals and are of particular relevance when selecting suitable procedures for monitoring biological effects.

We have included aspects of occupational monitoring in this review since poisoning from industrial causes may need hospital treatment. In the UK, employees exposed to lead at work must be monitored according to the Control of Lead at Work Regulations (Code of Practice 1985, updated 1998). ${ }^{7,8}$ This is normally the responsibility of Employment Medical Advisers (EMAs) or company Appointed Doctors (ADs), who are empowered to suspend an employee without loss of pay, institute remedial action and check on other employees who may be affected. General practitioners do not have all these powers, but may be consulted by employees, self-employed persons and those who have left such work or have performed it outside the UK.

\section{MECHANISMS OF TOXICITY}

Metals have been recognized as powerful toxins for many years. This has been reflected in their

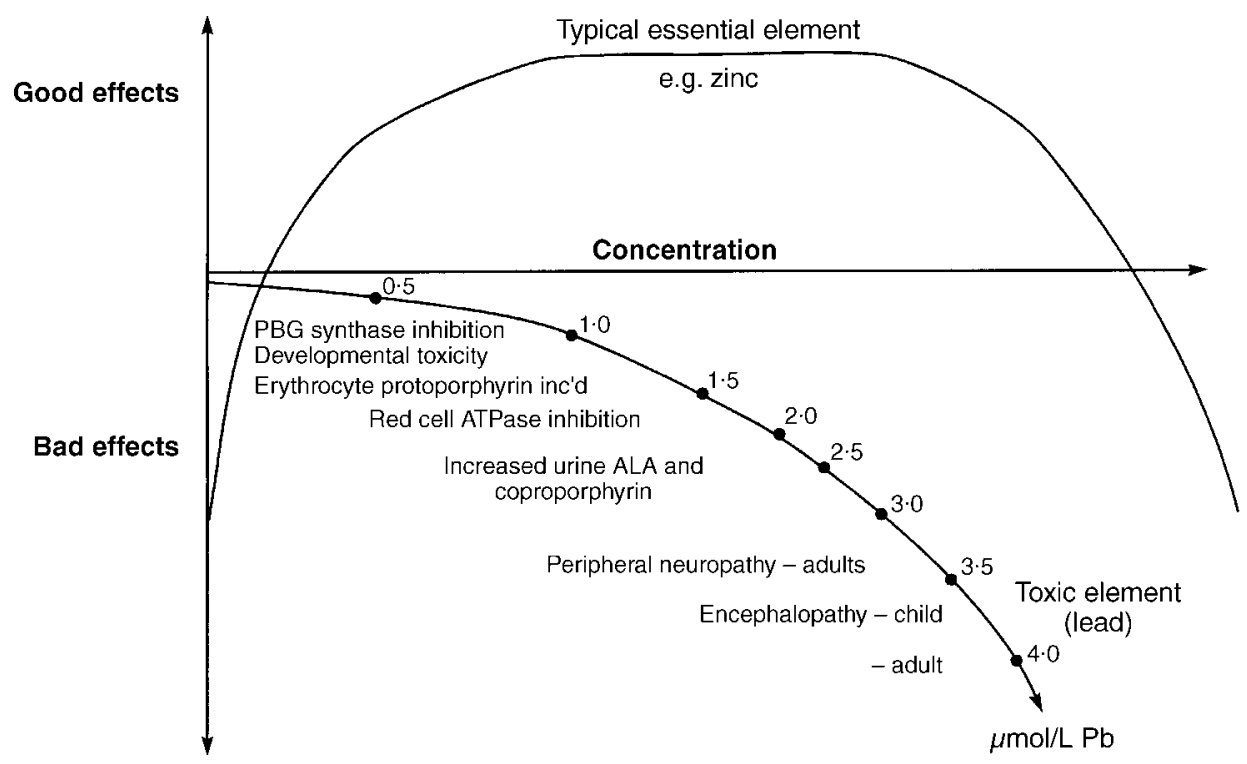

FIGURE 1. Bertrand's principle: the continuum of biological effects of exposure to a toxic element (lead) compared with an essential element (zinc). $P B G=$ porphobilinogen; ATPase $=$ adenosine triphosphatase; $A$ L $A=$ aminolaevulinic acid. 
wide clinical applications, for example as antibacterial agents (mercury, bismuth, lead), antihelminthics (thallium) and diuretics (organic mercurials). Man-made drugs are designed to have specific actions with minimal other effects, but in contrast, metals, although in some cases have specific actions, generally exert widespread effects throughout the organism. ${ }^{9}$ Some of these are indicated in Fig. 2.

Metals with small atomic radii often have important cellular functions which depend on the formation of their preferred co-ordination complexes with oxygen or nitrogen ligands of comparable size; for example, to control the quaternary arrangement in structural or catalytic domains of proteins (e.g., zinc and copper in superoxide dismutase), and in the transport of amino acids with sodium and of electrons by iron and copper in cytochrome $c$ oxidase. Light toxic metals (e.g., lithium and aluminium) may compete with or replace the metals they resemble. Heavier metals are less likely to be important physiologically. They have larger atomic radii, are more easily polarized and tend to form stable co-ordination complexes with equally large, polarizable, sulphydryl ligands. Toxic metals exert their effects by virtue of these co-ordination properties and their distribution through the body compartments. In addition, they may share certain physical or chemical properties with physiological elements near them in the periodic table. In acute poisoning, large excesses of metal ions can cause disruption of membrane and mitochondrial function with the generation of free radicals. Consequently, generalized clinical effects, including weakness and malaise, feature in most cases. However, despite the potential for metals to disrupt metabolic processes, the body has a considerable armoury of defence.

\section{EXTERNAL DEFENCES}

The epidermis usually forms an effective barrier against metals in the environment, although some topical creams may reduce its efficiency. A few metals are able to reach deeper layers. For example, chromium and nickel can cause dermatitis, and the fumes of certain metals, e.g., chromium(VI), can lead to severe ulceration of the nasal septum. Absorption of ingested metals from the gut is generally low; adults absorb no more than about $10 \%$ of ingested lead and rather less of aluminium. Children, especially the very young, probably absorb consider- ably more lead. ${ }^{10}$ The absorption of toxic metals can often be reduced by ensuring adequate dietary intakes of essential elements, because either there are dietary interactions or common uptake mechanisms which are stimulated by deficiency. With mercury as mercuric ion $\left(\mathrm{Hg}^{2+}\right)$, intestinal absorption is about $10 \%$, but as elemental mercury $\left(\mathrm{Hg}^{0}\right)$ it is negligible. In the lungs however, more than $80 \%$ of elemental mercury inhaled as vapour is absorbed. When metal-bearing dust particles are inhaled, the amount of metal absorbed is generally inversely proportional to the particle size.

\section{SEQUESTRATION}

In the body, toxic metals equilibrate with tissue and metabolic proteins, first in the vascular space and then in other compartments. Lead, aluminium, strontium and other metals may accumulate in bone to form a pool having a slow turnover rate and a long half-life, so reducing the immediate exposure of other tissues. This is a particular problem when they are also radioactive, e.g., americium. The accumulation may also have implications in situations with increased bone turnover or loss of bone, such as post-menopausally, in pregnancy, in renal failure or during treatment with cis-platinum. ${ }^{11,12}$ Toxic metals which fail to cross the basolateral membrane of the intestinal mucosal cells are eliminated when these are shed. For this reason, copper toxicity in Wilson's disease can be treated with high doses of zinc. The zinc induces synthesis of metallothionein (see next section) which binds copper in the cells and prevents its absorption. Other metals may be sequestered in the skin, e.g., silver in argyria.

\section{Protein complex formation \\ Metallothionein}

Metallothionein (MT) is a low molecular weight (6-7000 Da) intracellular protein with about $30 \%$ sulphur-containing amino acids, which is found in most phyla and has a highly conserved structure. Some $30 \%$ of its amino acids are sulphur-containing and high concentrations are found in liver, kidney, intestine and pancreas. MT is known to be important in the regulation of copper and zinc metabolism and in the detoxification of heavy metals, particularly cadmium. However, the fundamental role of MT is still not understood, despite extensive use of its promoter gene and transcription control mechanisms as tools in molecular biology. Its 


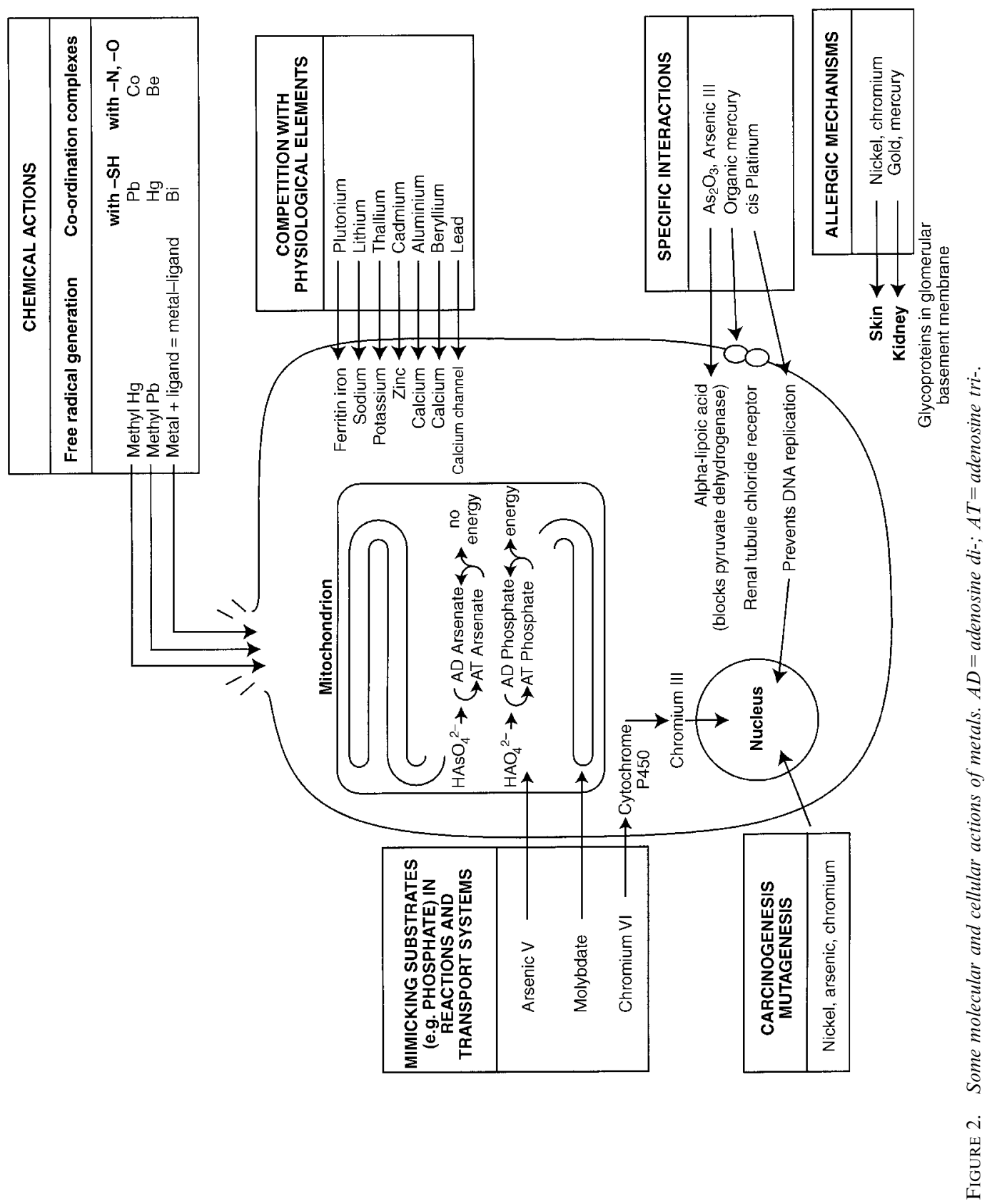


clinical significance has recently been thoroughly reviewed by Coyle et al. ${ }^{13}$

MT has alpha (C-terminal) and beta $(\mathrm{N}$ terminal) domains and can bind at least 18 different elements. Up to 7 atoms of most metals (e.g., zinc, cadmium) can usually be bound (4 alpha, 3 beta) but up to 12 atoms of a few metals, e.g., copper, can be bound. Synthesis of MT is induced by many substances, including zinc, cadmium, copper, mercury, gold, bismuth and some non-metallic compounds (although often at non-physiological concentrations), but intracellular zinc must be available for this to occur. Synthesis is regulated by interactions with glucocorticoids and a multiplicity of inflammatory mediators. An increase in MT is one of the earliest cellular events in the acute phase response and may be a means of increasing zinc availability for protein synthesis.

In hepatocytes, MT is metabolized in lysosomal or non-lysosomal compartments, according to the metal bound; its half-life in liver also depends on the metal bound, being about $80 \mathrm{~h}$ for cadmium-MT and $20 \mathrm{~h}$ for zinc-MT. Plasma MT concentration rises in response to cadmium or copper toxicity and in the acute phase response. It falls in zinc deficiency. Induction of MT by pretreatment with zinc has been shown to reduce the toxicity of many elements in animals and of cadmium in humans.

\section{Nuclear inclusion bodies}

Lead, bismuth and mercury all give rise to characteristic eosinophilic nuclear inclusion bodies in renal tubular cells. These are insoluble protein complexes and form soon after the commencement of exposure. They can sometimes be detected in urine, but it is not clear whether this is due to an active excretory process, or passive shedding of tubular cells. ${ }^{14}$ Haemosiderin formation represents a similar mechanism for sequestering excess iron.

\section{BIOTRANSFORMATION}

Several toxic elements are metabolized in the body. Mercury, arsenic and selenium can be methylated and demethylated by several pathways. Reductive methylation of arsenate $\left[\mathrm{As}(\mathrm{V}) \mathrm{O}_{4}{ }^{3-}\right]$ via arsenite $\left[\mathrm{As}(\mathrm{III}) \mathrm{O}_{3}{ }^{3-}\right]$ leads to formation of less toxic monomethylarsonic and dimethylarsinic acids, which can be excreted. Excess selenium is excreted as trimethylselonium ion unless exposure is great, in which case volatile dimethylselonium is formed. (This gives the breath a characteristic garlic odour, a biological effect which individuals can monitor for themselves.) Methylation of mercury, lead and tin produces metabolites which are more toxic. Tetramethyl derivatives of lead and tin are dealkylated in the hepatic microsomal cytochrome P450-mediated monoxygenase pathway. ${ }^{15}$ Elemental mercury is oxidized to mercuric ions via the catalase-mediated hydrogen peroxide pathway.

\section{THERAPEUTIC APPROACHES TO METAL POISONING}

Dialysis, haemofiltration and plasma exchange have all been used in attempts to reduce circulating levels of metal in acute poisoning, sometimes in conjunction with chelating agents. However, once the metal has become distributed through extravascular compartments, so much is bound in tissues that removal of the metal from blood has a negligible effect. Thus, benefit is only achieved if these techniques are tried early, although they may become necessary to manage renal failure arising as a consequence of the poisoning.

Although there are specific antidotes to certain metals, e.g., Prussian blue for thallium, treatment is generally by the use of chelating agents. These were first developed in World War Two, when British Anti-Lewisite (BAL, dimercaptopropanol) was introduced for use against mustard gas. Later, this compound was used for the removal of copper in Wilson's disease, until the introduction of oral penicillamine. Not all chelating agents are suitable for therapeutic use, and Table 3 indicates the criteria required.

Dimercaptosuccinic acid (DMSA, Succimer) and dimercapto-1-sulphonate (DMPS, Unithiol) are examples of new agents which are effective at chelating lead and mercury and have the advantage that they can be given orally. They belong to a family of compounds derived from BAL, but are less unpleasant. ${ }^{16}$ In the USA, DMSA is now approved for chelation therapy in children, and in the UK both agents are available on a named-patient basis from the Medical Toxicology Unit, Guy's and St Thomas's Hospitals NHS Trust (London). Few adverse effects have been noted so far, but these agents have not been in use long and prospective trials are awaited. ${ }^{17}$

With most chelation therapy it is essential that the agent is not administered while external sources of exposure (including any in the 
TABLE 3. Criteria for the suitability of chelating agents for therapeutic use

- Available in a suitable form for administration, preferably orally

- Neither the agent nor its chelate with the element must be toxic

- Any side effects should be minimal, e.g., ethylenediaminetetra-acetic acid (EDTA) must be given as the calcium salt because it chelates calcium and other essential elements as well as lead

- The agent and chelate must not be metabolized and release or redistribute the element, e.g., citrate is a good chelating agent, but is readily metabolized

- The thermodynamic association constant for the agent with element must be favourable compared with that for the element and body constituents

- The chelate must be excreted readily in urine or bile

intestines) remain, otherwise uptake may be dramatically enhanced. ${ }^{18}$ Iron is an exception to this important caveat, as any present in the intestine becomes effectively unavailable because the chelating agent desferrioxamine, a bacterial siderophore, binds so strongly to iron when given parenterally. Blood concentrations of metals frequently rise further during chelation therapy, since most analytical techniques measure the total amount, including the chelate. Once the chelate has been excreted, blood concentrations fall below pretreatment values, but may subsequently rebound as the vascular space is replenished from other body compartments. Careful monitoring of this rebound is essential to ascertain whether further chelation may be necessary.

\section{CADMIUM}

Cadmium has an atomic mass of 112. It is one of the commonest environmental metal poisons, largely because of human activities, particularly zinc, lead and copper (which occur in mixed ores with cadmium) smelting, although areas of high natural cadmium content do exist. In addition, cadmium is used in welding and brazing, in alloys and in the manufacture of batteries, while its compounds are widely employed as pigments and stabilizers in the paint, plastics and print industries. Cadmium usage has increased during the last 50 years and has resulted in contamination of more areas of land. Human health problems due to cadmium have been identified in five of thirteen such areas in Japan and increased prevalence of tubular proteinuria associated with environmental cadmium pollution has been reported in parts of China ${ }^{19}$ and Belgium $^{20}$ but not in all such areas. ${ }^{21}$ Air and water cadmium concentrations in unpolluted areas are low and normal dietary intake is less than $267 \mathrm{nmol}(30 \mu \mathrm{g}) / 24 \mathrm{~h}$, of which adults absorb 2-8\%. The amount absorbed varies inversely with the plasma ferritin concentration. Inhaled cadmium is more efficiently absorbed and twenty cigarettes may contribute 18$36 \mathrm{nmol}$ cadmium $(2-4 \mu \mathrm{g}){ }^{22}$ The main concerns with cadmium are therefore chronic exposure in populations and prevention of accumulated renal burdens from exceeding a critical concentration. Much knowledge has been gained from studies among populations exposed to cadmium either occupationally or through living in polluted environments. However, acute poisoning from inhalation of fumes or ingestion of cadmium salts can occur and at least one death from self-poisoning with cadmium chloride has been reported. ${ }^{23}$

\section{Toxicokinetics}

After absorption, cadmium is transported in the blood bound to albumin. It is taken up by the liver, where it induces synthesis of MT, to which it binds. Subsequently, cadmium-MT is released into the circulation, filtered by the kidneys and reabsorbed by endocytosis into the cells of the proximal tubules, which are the critical organs. The complex is degraded in the lysosomes and cadmium atoms are freed, either to recombine with MT synthesized locally or to initiate toxic processes. Cadmium thus accumulates in renal tubular cells, with a half life of $17-30$ years, ${ }^{6}$ until their synthetic capacity for MT is exceeded. This occurs at a critical concentration in renal cortex of about $1600 \mathrm{nmol}(180 \mu \mathrm{g})$ cadmium/g. Cadmium then binds to other ligands, irreversible renal damage ensues, renal cadmium declines and its urinary excretion rises sharply. There is characteristic, but mild, low-molecularweight renal tubular proteinuria, progressing to hypercalciuria, glucosuria, phosphaturia and amino aciduria. The hypercalciuria is an early finding and calcium excretion is correlated with urinary cadmium; whether this effect is primary or secondary to the tubular damage remains unresolved. ${ }^{24}$ Effects of cadmium on the synthesis of procollagen by human lung fibroblasts in vitro have also been reported, consistent with the 
idea that slowing of repair processes in lungs leads to connective tissue damage, a possible role for cadmium in the lung disease of smokers and occupationally exposed persons. ${ }^{25}$

There is some evidence that the tubular proteins currently used for monitoring occupational cadmium exposure may reflect irreversible damage to the tubules. ${ }^{26}$ In an effort to develop and validate earlier markers for nephrotoxic effects, a collaborative European project has studied changes in urinary and serum constituents following industrial exposure to lead, mercury and cadmium. ${ }^{27}$ For cadmium, the threshold concentration (defined as the level at which $10 \%$ of individuals will show the change) varied considerably for the different markers listed in Table $4 .{ }^{28}$ The authors postulated that these thresholds reflect a progression from (a) tubular cell alterations with minor biochemical changes only, followed by (b) a reduction in negative charge at the glomerular basement membrane leading to increased permeability, with raised excretion of high-molecular-weight proteins in some individuals, followed by (c) continuing tubular cytotoxicity progressing to actual tubular damage with increased excretion of low-molecular-weight markers, e.g., beta-2microglobulin (beta-2-M) and retinol-binding

TABLE 4. Values of urinary cadmium associated with a significantly higher probability of abnormal values for renal markers in adult male cadmium workers

Urinary cadmium concentration (nmol/ mmol creatinine) at which $10 \%$ of subjects show elevated

Marker measured marker concentration

\begin{tabular}{ll}
\hline 6-Keto-prostaglandin $F_{1-\text { alpha }}$ & $2 \cdot 4$ \\
Sialic acid & $2 \cdot 4$ \\
Transferrin & $3 \cdot 6$ \\
Brush border antigen & $3 \cdot 7$ \\
N-acetyl-beta-D-glucos- & \\
aminidase & 4 \\
Intestinal alkaline phosphatase & $4 \cdot 1$ \\
Albumin & $4 \cdot 1$ \\
Tamm-Horsfall glycoprotein & 7 \\
Tissue non-specific alkaline & \\
phosphatase & $9 \cdot 7$ \\
Brush border antigen HF5 & 10 \\
Retinol-binding protein & $10 \cdot 4$ \\
Glycosaminoglycans & $11 \cdot 5$ \\
Beta-2-microglobulin & $11 \cdot 5$ \\
Beta-2-microglobulin (serum) & $6 \cdot 1$ \\
\hline
\end{tabular}

Adapted with permission. ${ }^{28}$ protein (RBP). The health significance of these observations remains to be established and confirmed in other exposed workers, but may be important in future monitoring programmes.

Similar changes in excretion of marker proteins in environmental exposure cannot be assumed, since the route of exposure is more exclusively oral. However, increased excretion of calcium beta- $\mathrm{N}$-acetylglucosaminidase, RBP and beta-2-M were found at urinary cadmium thresholds of $2 \mathrm{nmol} / \mathrm{mmol}$ creatinine in one large study. ${ }^{29}$

\section{Clinical manifestations}

Welders or cutters who accidentally inhale cadmium fumes develop a 'fume fever', a pneumonitis with cough, dyspnoea and also myalgia, which may progress after $24-48 \mathrm{~h}$ to potentially fatal pulmonary oedema. Lower acute exposure may produce reversible effects, but sometimes leads to massive progressive lung fibrosis. Chronic inhalation leads to obstructive airways disease and emphysema. ${ }^{30}$

In Japan, cases of Itai-Itai (meaning 'Ouch!Ouch!') disease were identified between 1940 and 1975 among populations living in cadmiumpolluted areas. In this condition there is proximal tubular damage, a mild anaemia and a severe loss of bone mineral which results in painful fractures. Multiparous and postmenopausal women are subject to particularly severe effects. However, in other countries with areas of comparable pollution, populations do not exhibit such severe symptoms. ${ }^{31}$ This may relate to other dietary influences. Disturbances of calcium metabolism have been noted among cadmium workers, variously leading to osteomalacia, osteoporosis and nephrocalcinosis, and this is more likely to occur in highly exposed subjects, and in those who have low dietary calcium and vitamin D intakes.

In some studies, cadmium exposure has been linked with increased mortality from cancers of the prostate and lungs. ${ }^{32,33}$ Although longerterm follow-up of the original groups has cast doubt over the link with prostatic cancer, the link with lung cancer persists in at least two studies. ${ }^{34,35}$ However, this could be due to the difficulty of excluding effects from associated elements known to be carcinogenic, e.g., arsenic or nickel. ${ }^{36}$ The unpredictable nature of any such risk would imply that dose-response monitoring was irrelevant and that only minimum exposure would be acceptable. In some early studies an association between hypertension and cadmium 
exposure was suggested, but this has not been confirmed in later studies. ${ }^{37,38}$

\section{Laboratory investigations}

Assessment of exposure and internal dose

In the blood $90 \%$ of cadmium is bound to erythrocytes and has a half life of 70-120 days. The blood concentration depends on both current exposure and body burden and is generally a better guide to the former than is urine cadmium, unless the body burden is high. Blood calcium increases during the first 4 months of exposure. ${ }^{39}$ Urinary cadmium excretion is low in non-occupationally exposed persons of both sexes and rises slowly until 55 years of age and then declines slightly. Both blood and urine concentrations are higher in smokers. ${ }^{40}$ Urinary cadmium excretion is positively correlated with cumulative exposure and with renal and hepatic concentrations, except when: (a) exposure is so great that all cadmium binding sites are used; (b) the critical concentration is exceeded; or (c) cadmium-induced renal tubular damage has occurred. Both whole blood and urine concentrations are therefore necessary for the assessment and monitoring of chronic cadmium exposure. The low values and the small increases that occur with time make cadmium assay particularly demanding. Nevertheless, within-laboratory relative SDs (CVs) better than $10 \%$ at concentrations in the unexposed ranges and better than $4 \%$ near occupational limits can be achieved in experienced hands.

The measurement of urinary MT offers little advantage over measurement of urine cadmium. In hair samples, cadmium measurement is subject to errors from contamination, while faecal cadmium is only an approximate guide to intake. Studies of hepatic and renal cadmium concentrations in vivo using direct neutron activation or X-ray fluorescence techniques have confirmed conclusions based on epidemiological, occupational and post-mortem work, but are too expensive and difficult for wide application. ${ }^{41,42}$

\section{Assessing the effects of exposure}

Urinary beta-2-M was the first biological effect marker for cadmium to be widely used, but it is increased in other conditions and degraded in bladder urine with a $\mathrm{pH}$ of below 6.0. Urinary RBP and alpha-1-microglobulin (alpha-1-M) also increase in response to renal tubular damage and are now often preferred because of their greater stability. ${ }^{43}$ Increases in beta-2-M and RBP are considered by some to reflect irreversible renal effects, which may progress following cessation of exposure, ${ }^{26}$ and new earlier markers, as discussed above, may replace them. Meanwhile, other workers consider a combination of high- and low-molecular-weight markers to be more effective than a single marker. Schaller et al. recommend albumin or transferrin as the high-molecular-weight marker, together with RBP or alpha-1-M, ${ }^{44}$ while Jung et al. and Mueller found alpha-1-M combined with the lysosomal enzyme beta-NAG exceeded reference limits in $30 \%$ of an environmentally exposed group and $39 \%$ of workers at a cadmium battery plant. ${ }^{45,46}$ Renal proteinuria from causes other than cadmium exposure, such as pregnancy, is not accompanied by an increase in urinary cadmium. ${ }^{47}$

Current UK guidelines for occupational monitoring of cadmium exposure and its effects are shown in Table $5 .^{48}$

\section{Treatment}

There are no specific methods which eliminate cadmium effectively and therapy is entirely supportive. This is why emphasis is on prevention of accumulation over long periods. New chelating agents are being developed which may be capable of reducing cadmium burden. ${ }^{49}$

\section{LEAD}

Lead has been used in industrial and domestic applications for hundreds of years. Its toxicity has been recognized for almost as long: Dioscorides in $200 \mathrm{BC}$ wrote that 'lead makes the mind give way' and Benjamin Franklin described the 'dry gripes' (colic) and 'dangles' (wrist drop)..$^{50,51}$ Lead presents one of the greatest challenges of modern times to those responsible for public health and industrial hygiene. Analytical epidemiological studies suggest that some degree of exposure is almost universal. ${ }^{52}$ Lead, its metabolism and its effects have been more extensively reviewed than any other metal. ${ }^{53-5}$

Since the 19th century Factory Acts, progressive legislation has resulted in stringent control of industrial hygiene and reduced the dangers of large-scale use of lead to a few cases each year in the UK (see Table 1). However, sporadic cases may be increasing. The sub-contracting of demolition work may lead to poor continuity of monitoring, and workers from small companies or those who are self-employed may risk 
TABLE 5. Cadmium reference values in blood and urine

(a) Unexposed subjects

\begin{tabular}{lll}
\hline & Non-smokers & Smokers \\
\hline Blood* & $<27 \mathrm{nmol} / \mathrm{L}(<3 \mu \mathrm{g} / \mathrm{L})$ & $<54 \mathrm{nmol} / \mathrm{L}(<6 \mu \mathrm{g} / \mathrm{L})$ \\
Urine & $<25 \mathrm{nmol} / 24 \mathrm{~h}(<3 \mu \mathrm{g} / 24 \mathrm{~h})$, or & \\
& $<2 \mathrm{nmol} / \mathrm{mmol}$ creatinine & \\
\hline
\end{tabular}

(b) Occupationally exposed subjects: guidelines

\begin{tabular}{lll}
\hline & Blood concentrations* & \\
\cline { 2 - 3 } Urine concentrations & $<90 \mathrm{nmol} / \mathrm{L}(<10 \mu \mathrm{g} / \mathrm{L})$ & $>90 \mathrm{nmol} / \mathrm{L}(>10 \mu \mathrm{g} / \mathrm{L})$ \\
\hline$<10 \mathrm{nmol} / \mathrm{mmol}$ creatinine $(<10 \mu \mathrm{g} / \mathrm{g})$ & $\begin{array}{l}\text { Maintain good hygiene and } \\
\text { monitoring }\end{array}$ & Check hygiene control \\
$>10 \mathrm{nmol} / \mathrm{mmol}$ creatinine $(>10 \mu \mathrm{g} / \mathrm{g})$ & $\begin{array}{l}\text { Investigate hygiene control, } \\
\text { check renal tubular function } \\
\text { and serum creatinine }\end{array}$ & $\begin{array}{l}\text { More rigorous hygiene control, } \\
\text { monitor renal tubular function } \\
\text { and serum creatinine }\end{array}$
\end{tabular}

*ethylenediaminetetra-acetic acid (EDTA) whole blood, $2 \mathrm{~mL}$. Tubes with red or yellow stoppers are likely to cause significant contamination.

acute exposure on top of a pre-existing body burden. People working in Continental Europe for short periods have presented on their return with manifestations of lead poisoning (Supraregional Assay and Advisory Service Trace Element Directors, personal communication). Episodes of poisoning from occasional causes such as imperfectly glazed ceramics, ${ }^{56}$ the use of medicines (which may contain as much as $60 \%$ lead ${ }^{57}$ ) available from Asian 'healers', and cosmetic preparations, may affect any age group, and cases may present as acute emergencies. The average daily intake has fallen with replacement of lead for soldering tins and for domestic water pipes. The use of lead in paint, though restricted in the UK, still presents serious problems when older buildings are redecorated, and the occasional child with pica may still present as an emergency with acute lead poisoning from ingested paint.

During the last decade the risk of exposure to low levels of inorganic lead affecting the behaviour and intelligence of children has been a major issue. In 1979 Needleman and co-workers published a study of dentine lead in children from the general population. ${ }^{58}$ Groups with high and low dentine lead were compared in neuropsychological tests and differences of about 4 IQ points were found. Some of these differences persisted in follow-up studies after 5 and 11 years. ${ }^{59}$ However, blood lead measurements in small subgroups of children from both groups during the first study [mean concentrations of $1.71 \mu \mathrm{mol} / \mathrm{L}(35.5 \mu \mathrm{g} / \mathrm{dL})$ and $1.15 \mu \mathrm{mol} /$ $\mathrm{L}(23.8 \mu \mathrm{g} / \mathrm{dL})$ in children with high and low dentine lead, respectively] suggest that they may all have suffered some exposure to lead. Dentine lead measurement has been shown not to be particularly reproducible. ${ }^{60}$ Nevertheless, other groups in the USA, Australia and Europe have reported similar relationships between blood lead concentrations and performance in intelligence and attainment tests. ${ }^{61-63}$ Not all of the results achieved significance and if they did, it often disappeared when they were adjusted for socioeconomic variables. In Edinburgh, 501 children aged between 6 and 9 years were studied; the geometric mean blood lead was $0.50 \mu \mathrm{mol} / \mathrm{L}(10 \cdot 4 \mu \mathrm{g} / \mathrm{dL})$. Blood lead concentrations correlated with performance in a range of ability and attainment tests, although the effects were small compared with those of other factors. The association remained after controlling for 33 confounding variables and was strongest for the younger children. ${ }^{64}$ Pocock et al. ${ }^{65}$ recently conducted a systematic review of 21 crosssectional and prospective surveys which included more than 100 children and concluded that 
doubling of the body burden [blood lead from 0.5 to $1.0 \mu \mathrm{mol} / \mathrm{L}(10-20 \mu \mathrm{g} / \mathrm{dL})$, dentine lead from 24 to $48 \mathrm{nmol} / \mathrm{g}(5-10 \mu \mathrm{g} / \mathrm{g})]$ is associated with a deficit of 1-2 points on the IQ scale. However, they acknowledged that a non-causal explanation for the association remained possible. In the USA, the scientific methods employed by Needleman for the original studies were criticized to the Office of Scientific Integrity.

The resulting public investigation was inconclusive. ${ }^{66}$ Nevertheless, it is difficult to ignore the trends noted in most studies. The debate culminated in 1991, when the US Centers for Disease Control published proposals to reduce the acceptable limit for blood lead, requiring each state in the Union to establish programmes of monitoring and abatement to ensure that no child between 0 and 6 years of age will be exposed to lead sufficient to raise the concentration in blood above $10 \mu \mathrm{g} / \mathrm{dL}(0.5 \mu \mathrm{mol} / \mathrm{L}){ }^{67}$ Since then several surveys conducted in different areas of the USA have expressed concern about the number of children who may now be classified as 'lead poisoned'. ${ }^{68}$

Two European Community-wide surveys of blood lead conducted between 1979 and 1981 recommended that $50 \%$ of the population should have values below $1.0 \mu \mathrm{mol} / \mathrm{L}(20 \mu \mathrm{g} /$ $\mathrm{dL}$ ), not more than $10 \%$ should be above $1.5 \mu \mathrm{mol} / \mathrm{L} \quad(30 \mu \mathrm{g} / \mathrm{dL})$ and fewer than $2 \%$ should exceed $1.7 \mu \mathrm{mol} / \mathrm{L}(35 \mu \mathrm{g} / \mathrm{dL})$. During the second campaign 3500 blood samples from adults and children at risk of undue exposure were surveyed; in only 3 out of 35 population groups were these criteria exceeded. ${ }^{69}$ Evidence is emerging that concentrations of lead in blood have fallen further as use of unleaded petrol has increased (Delves HT, personal communication). Figure 3 shows the decline in the 95th centile for blood lead concentrations in environmental surveys in the UK since 1985, when the availability of lead-free petrol was increased, with a consequent reduction in lead emissions from 7500 to 3000 tonnes per annum. ${ }^{70}$ The action limit recommended by the Department of Health for the UK remained at $1.21 \mu \mathrm{mol} / \mathrm{L}$ $(25 \mu \mathrm{g} / \mathrm{dL})$ and in France at $0 \cdot 7 \mu \mathrm{mol} / \mathrm{L}(15 \mu \mathrm{g} /$ dL) until Ministers for the Environment met in Miami for the G8 summit in May 1997. At this meeting, Ministers called for further actions that will result in reducing blood lead levels in children to below $0.5 \mathrm{mmol} / \mathrm{L}(10 \mu \mathrm{g} / \mathrm{dL})$ and confirmed the Commission's proposal to ban the marketing of leaded petrol in the EC from January $2000 .^{71}$ Australia had plans for staged

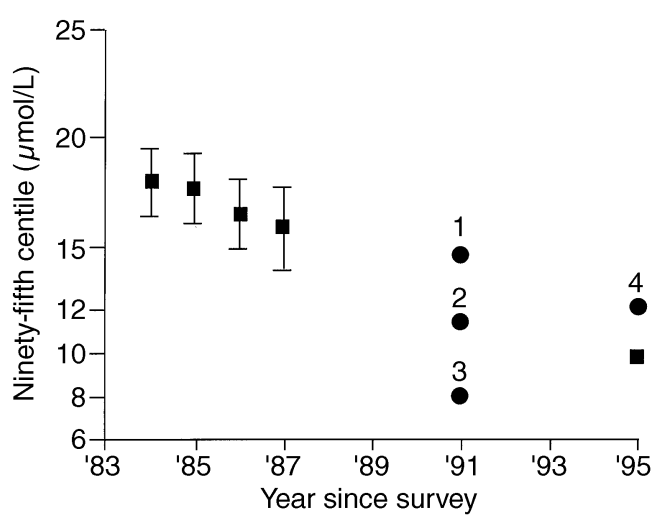

FIGURE 3. UK environmental lead monitoring: the decline in the 95th centile of concentrations for surveys conducted since 1983. = Adults and children (for 1984 $\mathrm{n}=2321$; for $1985 \mathrm{n}=2470$; for $1986 \mathrm{n}=2376$; for 1987 $\mathrm{n}=2306$; for $1995 \mathrm{n}=420$ ). $\bullet=$ Children only: $1=$ urban contaminated land, $\mathrm{n}=71 ; 2=$ raised water lead, $\mathrm{n}=158 ; 3=$ rural contaminated land, $\mathrm{n}=55 ; 4=$ mixed environments, $\mathrm{n}=280$.

reduction to $0 \cdot 7 \mu \mathrm{mol} / \mathrm{L}(15 \mu \mathrm{g} / \mathrm{dL})$ by 1998 and then to $0.5 \mu \mathrm{mol} / \mathrm{L}(10 \mu \mathrm{g} / \mathrm{dL})$. Despite the decline in blood concentrations noted above, it has been estimated that an appreciable number of children under 5 years of age in the UK may have blood lead concentrations above the new target limit. ${ }^{72}$ Analysis of the results of blood lead measurements in children referred to four UK Supraregional Assay and Advisory Service (SAAS) Trace Element laboratories between 1992 and 1997 show values above this limit in about 1 in 8 children (Fig. 4) (SAAS Directors, personal communication), with a slightly higher incidence of raised values in the younger age groups.

\section{Toxicokinetics}

In the body, about $5 \%$ of lead forms an exchangeable pool distributed between the soft tissues and blood. The remaining $95 \%$ is sequestered in the bone, as insoluble phosphates with a half life of $20-30$ years. There is some evidence that with prolonged exposure, less lead enters bone and more binds to proteins, possibly MTs, that have been demonstrated in the erythrocytes of persons exposed to lead. Such binding tends to increase the half-life of lead in the blood. ${ }^{73}$ About $93 \%$ of lead entering the blood is bound rapidly to erythrocyte membranes and haemoglobin with a half-life of about 


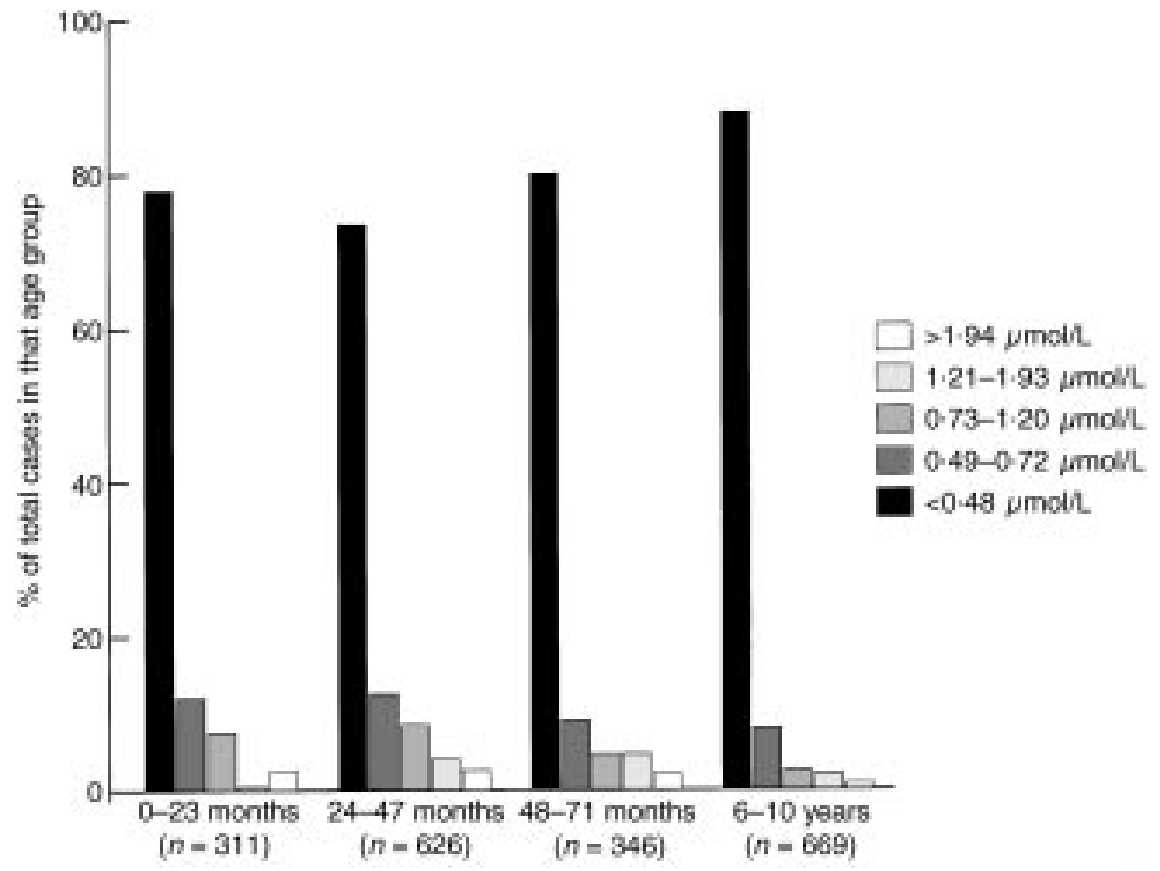

FIGURE 4. Blood lead concentrations in children ( $<11$ years) deemed clinically to be at risk of lead poisoning (1992-1997): results from clinical requests for lead analyses at four UK Supraregional Assay and Advisory Service (SAAS) Trace Element Units (Regional Toxicology Laboratory, Birmingham; King's College Hospital, London; Medical Toxicology Unit, Guy's Hospital, London; and Leeds General Infirmary).

35 days. ${ }^{74}$ In relatively unexposed persons, blood lead concentrations show a log-normal distribution. Concentrations are slightly higher in adult men, but below 12 years of age there is no difference between the sexes. Less than $0 \cdot 1 \mu \mathrm{mol}$ $(20 \mu \mathrm{g})$ lead per $24 \mathrm{~h}$ is normally excreted in the urine (House I, personal communication); almost all that present in faeces consists of unabsorbed lead.

Classically, the erythroid bone marrow has been the 'critical organ' and inhibition of erythrocyte porphobilinogen synthase (aminolaevulinic acid dehydratase, ALAD: EC 4.2.1.24) the 'critical effect'. This enzyme catalyses conversion of aminolaevulinic acid to porphobilinogen, and inhibition results in increased urinary ALA. The insertion of ferrous (Fe II) iron into the porphyrin ring to form haem is catalysed by the mitochondrial enzyme ferrochelatase (EC 4.99.1.2) which shows reduced activity in the presence of lead. This leaves the protoporphyrin free to form zinc protoporphyrin (ZPP), a highly fluorescent complex, which is characteristically increased in lead poisoning and also in iron deficiency. Once formed, ZPP remains in the erythrocyte for the life of the cell and it should theoretically be an ideal marker for the effect of lead exposure during the lifetime of the population of erythrocytes. Other enzymes along the haem synthetic path are also affected, particularly coproporphyrinogen oxidase (EC 1.3.3.3), which leads to increased urinary coproporphyrin excretion. All these metabolites have been widely employed as markers in screening and monitoring programmes for lead exposure.

Some recent work has challenged the assumption that lead inhibits ferrochelatase and coproporphyrinogen oxidase directly. Studies in lymphocytes have shown no loss of activity for either enzyme in the presence of lead, ${ }^{75}$ and in vitro ferrochelatase can use zinc or cobalt as alternatives to iron. In inherited deficiency of ferrochelatase (protoporphyria) only free protoporphyrin, not ZPP, is formed. Therefore, lead may act by inhibiting activity of the 
ferrireductase which reduces iron to the ferrous ion, thus limiting its supply to ferrochelatase so that ZPP formation is preferred. ${ }^{76}$ The overall decrease in haem production feeds back to stimulate the whole pathway with further increases in production of ZPP and intermediates and their urinary metabolites, principally aminolaevulinic acid and coproporphyrin. A microcytic hypochromic anaemia develops due to the effects of lead on globin synthesis, erythrocyte survival and haem oxygenase. The blood film appears similar to that seen in iron deficiency and reticulocytosis may also be present. Inhibition by lead of another erythrocyte enzyme, pyrimidine-5'-nucleotidase (EC 3.2.2.10), leaves clumps of RNA in the erythrocytes. These appear as basophilic stippling on blood films, which also occurs in inherited deficiency of the enzyme. This stippling is often the first sign to suggest the diagnosis. In a patient who presented with severe abdominal colic, it was this observation which indicated the real problem and halted consideration of a laparotomy. ${ }^{77}$

Figure 1 demonstrates the overall sequence of effects of lead in relation to the typical blood lead concentrations at which they occur. The latter are somewhat lower for children than for adults, but individual variation is high. ${ }^{78}$ For inorganic lead, there is now sufficient evidence that the central nervous system should be regarded as the 'critical organ' and the 'critical effects' are those on intelligence and cognitive function, which cannot be so conveniently identified in individuals as can the products from the haem pathway. The mechanisms of neurotoxicity remain obscure, but may include: (a) alteration in the permeability of endothelia, leading to cerebral oedema; (b) impaired sialylation of adhesion molecules affecting synapse formation; and (c) indirect effects due to the haem pathway metabolite aminolaevulinic acid on gamma-aminobutyric acid function. ${ }^{55}$

As exposure continues, the next organ to be affected is the kidney. Generalized tubular dysfunction results in amino aciduria (particularly glycinuria), phosphaturia and glycosuria. Lead-induced changes in haemopoietic and renal tubular function are not usually permanent unless the insult is continual or repeated. In the long term this may result in irreversible chronic interstitial nephropathy with a raised urate - 'saturnine nephropathy'. A recent study of leadworkers examined changes in a range of urinary constituents. ${ }^{79}$ The authors reported reduced excretion of eicosanoids, enhanced thromboxane excretion, and enhanced excretion of sialic acid. Excretion of tubular antigens was related to the duration of exposure. The significance of such findings is not yet clear, but may become important in future biological monitoring of the effects of exposure to lead.

In contrast to inorganic lead, organic lead is lipophilic and primarily affects the central nervous system. It does not bind to erythrocytes, so the blood lead concentration is not increased except by the small amount of inorganic lead formed by dealkylation.

\section{Clinical manifestations}

The classic presentation, with cerebral oedema leading to encephalopathy with high mortality or residual damage, used to be seen frequently in children from some urban environments, particularly during summertime. ${ }^{80}$ This is now rare in developed countries. Peripheral and autonomic neuropathies continue to occur. The former is uncommon in children, but weakness, paraesthesiae and wrist drop (painter's palsy) occur in severely poisoned adults, ${ }^{81}$ while reduced motor nerve conduction velocities are found at lower blood lead concentrations. Autonomic neuropathy results in abdominal colic and pain, sometimes with diarrhoea and vomiting, sometimes with constipation. Abdominal symptoms, together with marked general weakness, fatigue and malaise are the most common presenting symptoms. Upper abdominal pain is said to indicate more acute exposure, while lower abdominal symptoms may suggest a more chronic exposure. $^{78}$ Children frequently present with peculiar eating habits (pica), often exacerbated by iron deficiency; the possibility of lead poisoning should be investigated in all such cases and probably considered in all children with iron deficiency or learning difficulties. Radiography of the hands and feet may show lead lines at the epiphyses which suggest longstanding exposure. Rarely, in both adults and children, a blue line around the gums may be apparent.

Exposure to organic (usually tetramethyl or tetraethyl) lead is rare, thanks to stringent regulation, but can occur following petrol sniffing, although symptoms of hydrocarbon toxicity usually predominate. Poisoning results in a predominantly neurological picture, with symptoms such as vomiting, weakness, fatigue, anorexia, confusion and convulsions. 


\section{Laboratory investigation}

Assessment of exposure and internal doses

The 'gold standard' for estimating the internal dose of lead has been measurement of its excretion after the administration of $1 \mathrm{~g}$ of calcium ethylenediaminetetra-acetic acid (EDTA) (as an i.v. infusion or i.m. injection). Excretion during the next $24 \mathrm{~h}$ of more than $3.9 \mu \mathrm{mol}$ $(800 \mu \mathrm{g})$ lead in adults, or $2 \cdot 9-3 \cdot 4 \mu \mathrm{mol}(600$ $700 \mu \mathrm{g})$ in children, indicates a raised body burden. Unfortunately, a number of protocols have been employed, for which the cut-off points vary. In the USA this test has been recommended for deciding whether or not to treat children with borderline blood lead concentrations. However, some experiments in animals have suggested that even a single dose of chelating agents may result in redistribution of some lead from bone to soft tissues, including the brain. ${ }^{82}$ This has prompted a consideration of alternative tests as well as a plea for more resources for abatement programmes to reduce lead exposure. ${ }^{83}$ In the UK this test is not widely used, but may occasionally be of assistance, e.g., when there is suspicion of multiple episodes, or of past exposure, as in children with pica. ${ }^{84}$

Blood lead and analytical performance standards The concentration of lead in blood shows good correlation with the EDTA excretion during periods of exposure to inorganic lead and it is now regarded as the measurement of choice for investigating environmental, acute or occupational exposure in the UK. Following cessation of exposure, the relationship is less exact, but if the body burden is high, blood lead may remain elevated for years, reflecting 'internal exposure' from the bone compartment.

In the past, the analysis of blood lead was time-consuming and difficult. Blood samples were often collected using fingerprick techniques or venesection in dusty workplaces and the incidence of contamination was notorious. Today, industrial hygiene is better and venesection simpler, so contamination is less frequent. Nevertheless, elevated concentrations should always be confirmed in a further sample (urgently if necessary). Contamination from other sources can also occur. In 1991, large batches of rubber cap liners used by several manufacturers of blood sample tubes were found to be contaminated..$^{85,86}$

Since the 1970s a dramatic improvement in the performance of blood lead analysis has been brought about by three major develop- ments: (a) the advent of graphite furnace atomic absorption techniques; (b) the establishment of various national and international external quality assessment programmes, ${ }^{87,88}$ and (c) characterization of stable reference materials suitable for use in internal control procedures by the Supraregional Assay and Advisory Service Trace Element laboratories. ${ }^{2}$ Reductions in acceptable concentrations for lead, requirements for longitudinal stability in occupational and environmental monitoring and the interlaboratory accuracy necessary for large surveys, contribute to the need for performance to be specified and for stringent control protocols. ${ }^{89}$ For example, during the second European Community environmental survey of blood lead concentrations, $10 \%$ of all blood samples were exchanged between pairs of laboratories and a further $10 \%$ were re-analysed in a central laboratory. The differences between the paired estimates had to match certain criteria, i.e., $80 \%$ of differences less than $0.2 \mu \mathrm{mol} / \mathrm{L}(4 \mu \mathrm{g} / \mathrm{dL})$. The UK laboratories, analysing 716 blood samples containing $0 \cdot 2-$ $3.0 \mu \mathrm{mol} / \mathrm{L}(4-60 \mu \mathrm{g} / \mathrm{dL})$ lead achieved over $95 \%$ of differences less than $0 \cdot 2 \mu \mathrm{mol} / \mathrm{L}(4 \mu \mathrm{g} / \mathrm{dL}){ }^{69}$ Minimum standards in external quality assessment have been enforced for some time among UK laboratories undertaking occupational monitoring. A new portable instrument for analysing lead is currently being evaluated in the USA.

Urinary lead Measurement of lead in urine is appropriate when exposure to organic, e.g., tetraethyl, lead is suspected. For persons occupationally exposed to organic lead, the frequency of monitoring is governed by the expected concentration (Table 6) and the Employment Medical Adviser. ${ }^{8}$ Urinary lead concentration can also be used for monitoring chelation therapy.

Faecal lead Measurement of faecal lead is occasionally useful to confirm the suspected route of exposure, e.g., in the occasional case of factitious lead poisoning. ${ }^{90}$

Hair lead The analysis of hair for trace and toxic elements was well reviewed by Taylor in 1986. ${ }^{91} \mathrm{He}$ concluded that variation in factors affecting concentrations (sex, age, colour, cosmetic, hair site, hair length, sample preparation) varied so much that valid use had been demonstrated only for certain toxic metals in particular situations. For lead, hair analysis does 
TABLE 6. Lead reference values in blood and urine

(a) Unexposed subjects

\begin{tabular}{lll}
\hline & & Action \\
\hline Blood* concentration & $<0.48 \mu \mathrm{mol} / \mathrm{L}(10 \mu \mathrm{g} / \mathrm{dL})$ & None required \\
& $>0.48 \mu \mathrm{mol} / \mathrm{L}(10 \mu \mathrm{g} / \mathrm{dL})$ & In children eliminate exposure \\
& $>1 \cdot 21 \mu \mathrm{mol} / \mathrm{L}(25 \mu \mathrm{g} / \mathrm{dL})$ & $\begin{array}{l}\text { In children under } 6 \text { years, consider } \\
\text { treatment if lead fails to fall after } \\
\text { elimination of exposure }\end{array}$ \\
& & In children swift action \\
& $>2.9 \mu \mathrm{mol} / \mathrm{L}(60 \mu \mathrm{g} / \mathrm{dL})$ & In adults consider treatment \\
Urine ${ }^{\dagger}$ excretion & $<100 \mathrm{nmol} / 24 \mathrm{~h}(20 \mu \mathrm{g} / 24 \mathrm{~h})$ & None required
\end{tabular}

(b) Occupationally exposed subjects (inorganic lead) ${ }^{8}$

Newly appointed employees have an initial medical assessment and annual assessments thereafter. Where significant lead exposure is present or suspected, lead is monitored at 3 monthly (for inorganic lead) or 6 weekly (for organic lead) intervals, together with other relevant biological tests as required by the company Appointed Doctor or Employment Medical Adviser

\begin{tabular}{|c|c|c|}
\hline & $\begin{array}{l}\text { Action level } \\
\text { prompts investigation of } \\
\text { reasons for elevation; } \\
\text { a review of hygiene control; } \\
\text { direct medical surveillance, } \\
\text { and more frequent } \\
\text { monitoring }\end{array}$ & $\begin{array}{l}\text { Suspension level } \\
\text { prompts immediate } \\
\text { confirmation with a second } \\
\text { sample and suspension or } \\
\text { transfer from work exposing } \\
\text { employee to lead (for certain } \\
\text { exceptions, see Regulations) }\end{array}$ \\
\hline Inorganic lead & {$\left[\right.$ Blood* $^{*}$ lead $\left.\mu \mathrm{mol} / \mathrm{L}(\mu \mathrm{g} / \mathrm{dL})\right]$} & [Blood* lead $\mu \mathrm{mol} / \mathrm{L}(\mu \mathrm{g} / \mathrm{dL})]$ \\
\hline Women of reproductive capacity & $1 \cdot 2(25)$ & $1 \cdot 4(30)$ \\
\hline Young persons $<18$ years & $1.9(40)$ & $2 \cdot 4(50)$ \\
\hline All others & $2 \cdot 4(50)$ & $2 \cdot 9(60)$ \\
\hline Organic lead & $\begin{array}{l}{\left[\mathrm{Urine}^{\dagger} \text { lead nmol } / \mathrm{mmol}\right.} \\
(\mu \mathrm{g} / \mathrm{g}) \text { creatinine }]\end{array}$ & $\begin{array}{l}\text { Urine }^{\dagger} \text { lead nmol } / \mathrm{mmol} / \mathrm{L} \\
(\mu \mathrm{g} / \mathrm{g}) \text { creatinine }]\end{array}$ \\
\hline Women of reproductive capacity & $9 \cdot 7(20)$ & $12(25)$ \\
\hline All others & $45(95)$ & $53(110)$ \\
\hline
\end{tabular}

$* 2 \mathrm{mls}$ ethylenediaminetetra-acetic acid (EDTA) blood is preferred. ${ }^{\dagger} 20 \mathrm{~mL}$ urine in sterile universal container.

not show good correlation with blood lead concentrations, but has been applied to cases of gross poisoning and in environmental surveys when aerial lead contamination is relevant.

Isotope ratios Naturally occurring lead comprises four stable isotopes: ${ }^{204} \mathrm{~Pb},{ }^{206} \mathrm{~Pb},{ }^{207} \mathrm{~Pb}$, ${ }^{208} \mathrm{~Pb}$. Their proportions depend on the age of the lead and its geological origin. Isotopes can be determined using inductively coupled plasma atomic absorption with mass spectrometry. By comparing the abundance ratios of the lead isotopes in biological samples with those in potentially toxic environmental or other material, the source of lead exposure can be confirmed. ${ }^{22,93}$
Assessing the effects of exposure

Zinc protoporphyrin ( $Z P P$ ) ZPP is not affected by lead contamination and is readily measured in haematofluorimeters, which are convenient and portable. It has been used to screen children for lead poisoning, particularly where prevalence was great and exposure high ${ }^{94}$ and is still important in such areas where resources are limited. However, several studies have shown that when blood lead concentrations are below $2 \mu \mathrm{mol} / \mathrm{L}(40 \mu \mathrm{g} / \mathrm{dL})$ many children have a normal ZPP and would not be detected. ${ }^{95,96}$ The reason is that ZPP starts to rise exponentially only at blood lead concentrations above $1.5 \mu \mathrm{mol} / \mathrm{L}(30 \mu \mathrm{g} / \mathrm{dL})$ (for adults) or $1.2 \mu \mathrm{mol} / \mathrm{L} \quad(25 \mu \mathrm{g} / \mathrm{dL})$ (for children), i.e., at 
blood lead concentrations now considered high in the UK. ZPP does have a role in the evaluation of the effects of lead, to ascertain whether exposure is acute, fluctuating or chronic since, in the absence of iron deficiency, ZPP represents the average lead exposure during the lifespan of the erythrocytes.

Porphobilinogen synthase Inhibition of this enzyme in the cytosol of erythrocytes is the first measurable response to lead exposure (Fig. 1). It has been used in monitoring the effects of occupational exposure in some European countries. Theoretically, it should be relevant at the new limits for blood lead concentration in the USA. Quantifying this inhibition by measuring reactivation of the enzyme with zinc or dithiothreitol is difficult; ${ }^{97}$ the enzyme is not stable and in children total activity is low.

Other tests Inspection of Fig. 1 makes it clear that as the acceptable limits for exposure from environmental or occupational sources have been reduced, most measurable biological effects are now insufficiently sensitive to be of use. Urinary ALA and coproporphyrin both rise exponentially as blood lead concentration increases and, although much used in the past, are now appropriate only at higher occupational exposures. Abnormalities of renal tubular function may be demonstrable, with increased excretion of amino acids (particularly glycine), phosphate and glucose. Plain radiographs of the abdomen are important in revealing the presence of ingested or other lead, e.g., from paint, toys or gunshots. Careful neurological investigation is required, although the subtle deficits at low exposure cannot be detected in individuals.

\section{Responding to a raised blood lead}

The finding of a raised blood lead concentration should prompt a request for confirmation, the urgency depending on the level. In asymptomatic patients chelation therapy is generally not considered unless the blood lead is above $3.0 \mu \mathrm{mol} / \mathrm{L}(60 \mu \mathrm{g} / \mathrm{dL})$ in adults. In children, heightened appreciation of the risks and generally falling blood lead concentrations means that chelation therapy may now be considered at concentrations above $1.2 \mu \mathrm{mol} / \mathrm{L}(25 \mu \mathrm{g} / \mathrm{dL})$ if there is no response to removal from the source. Whenever exposure is indicated, vigorous attempts must be made to identify and eliminate the source. For leadworkers, the frequency of biological monitoring depends on the blood lead concentration and type of exposure according to the Code of Practice for the Control of Lead at Work and it is the responsibility of the company Appointed Doctor to ensure suitable monitoring and to take appropriate action if the suspension level is breached. New lower limits have taken effect from April 1998 (Table 6). In these, the monitoring of women of reproductive capacity and young people are considered separately for the first time and there are action limits and suspension limits. These limits are defined in $\mu \mathrm{g} /$ $\mathrm{dL}$ and are the reason why some blood lead measurements in the UK are reported in these units as well as in $\mu \mathrm{g} / \mathrm{L}$ or $\mu \mathrm{mol} / \mathrm{L}$. Particular care must therefore be taken to interpret blood lead results and ranges correctly (see Appendix 1 for conversion factors) especially when a result may be communicated through several laboratory systems.

\section{Treatment}

If the blood lead concentration is not greatly raised and the patient is well, elimination of the source of lead and ensuring adequate dietary calcium, iron and zinc, together with a low fat intake, may be all that is required. Should the blood lead concentration remain elevated, treatment with oral agents may be necessary; the newer dimercaptosuccinic acid (DMSA, Succimer, McNeil Consumer Products Co, Fort Washington, PA, USA) is more effective than penicillamine. For acutely ill patients, intravenous EDTA (Ledclair, Sinclair Pharmaceuticals Ltd, Godalming, Surrey, UK) can be used (as the calcium salt to prevent the severe consequences of excessive calcium loss). Much zinc as well as lead can be lost during treatment.

\section{Case history 1: lead poisoning \\ Presentation}

A child aged 7 years presented to her GP in 1991 with anaemia. Her haemoglobin was $41 \mathrm{~g} / \mathrm{L}$ and she was referred to a paediatrician. She was pale and small, but not unwell. She was fussy with food, preferring only milk and was said to eat plaster off the walls. Seven other children, older and younger, were well. Her blood lead was $2.0 \mu \mathrm{mol} / \mathrm{L}(41 \mu \mathrm{g} / \mathrm{dL})$; zinc protoporphyrin was $197 \mu \mathrm{g} / \mathrm{g}$ haemoglobin (upper reference limit $2 \mu \mathrm{g} / \mathrm{g}$ ). One week later, the blood lead had risen to $3 \cdot 3 \mu \mathrm{mol} / \mathrm{L}(68 \mu \mathrm{g} / \mathrm{dL})$. An abdominal radiograph showed opaque material in her stomach, presumed to be plaster. There was no evidence of renal tubular involvement nor of lead lines in her bones. 


\section{Management}

The rising blood lead concentration at week 2 prompted admission to hospital, to remove her from the source. Further increase in the blood lead could have incurred the risk of serious symptoms including encephalopathy. It was considered that the lead was actually causing her symptoms, so after ingested lead had been allowed to clear from the intestine she was treated with oral DMSA (had treatment been commenced before the lead had cleared, its absorption would have been enhanced). After treatment, her blood lead fell and subsequent weekly monitoring showed a rebound to $2 \cdot 3 \mu \mathrm{mol} / \mathrm{L}(47 \mu \mathrm{g} / \mathrm{dL})$ which was not treated further [current practice (1998) would probably have been to continue treatment until her blood lead was below $0.72 \mu \mathrm{mol} / \mathrm{L}(15 \mu \mathrm{g} / \mathrm{dL})$.] Urinary excretion of lead was $2 \cdot 3 \mu \mathrm{mol} / \mathrm{L}(480 \mu \mathrm{g} / \mathrm{L})$ at the end of treatment and fell to $0.3 \mu \mathrm{mol} / \mathrm{L}$ $(60 \mu \mathrm{g} / \mathrm{L})$ two days after cessation of therapy. She was given iron supplements and attempts were made to ensure her diet contained plenty of calcium and zinc, with a low fat content.

Identification of exposure Blood lead concentrations in the siblings were normal. Had they been raised, some common cause such as paint dust at school or home, toys, cosmetics, medicines or household water would have been likely. In such a case, testing the parents would provide further clues. Environmental investigation indicated that the source of lead was the plaster in the house, and a recommendation was made that the family should be rehoused. Attempts to persuade the family to reduce the exposure in the interim by sending the child to her grandmother were unsuccessful.

\section{THALLIUM}

This element has an atomic mass of 204.59 and so is truly 'heavy', binding readily to sulphydryl ligands. Its salts are colourless, odourless and tasteless, as well as quite soluble in water, so that they easily pass undetected. They are exceedingly poisonous. Ingestion of more than 10 $15 \mathrm{mg} / \mathrm{kg}$ can be lethal. Thallium achieved notoriety at the hands of the St Albans poisoner..$^{98}$ In past times, thallium had a variety of medical applications, including the treatment of scalp ringworm. Such use has been banned in the UK since 1940, but thallium is still used as a rodenticide in some parts of the world. Thallium isotopes are used in clinical imaging. Industrial uses, including the manufacture of optical glass, semiconductors, low-temperature thermometers and switches, catalytic processes and green fireworks are closely regulated by licensing. Poisoning is generally the result of ingestion, but cases due to inhalation of dusts, fumes from smelting, skin absorption and even from sniffing contaminated cocaine have been reported. ${ }^{99-101}$

\section{Toxicokinetics}

During the first few hours after ingestion thallium is distributed throughout the vascular space. Thereafter, up to about $48 \mathrm{~h}$, it enters the central nervous system (CNS) and other tissues. Because thallium closely resembles potassium in ionic size and charge, its distribution volume is large. Elimination commences after about $24 \mathrm{~h}$. Approximately two-thirds of ingested thallium is secreted into the intestine, from which significant reabsorption occurs. The remaining one-third is excreted in urine. The elimination half-life may be up to 30 days, but can be reduced to as little as two days depending on the therapeutic intervention. The pattern is at least biphasic, with a slow final stage. ${ }^{102}$

The toxicity of thallium depends on its ability to combine with sulphydryl groups of molecules in mitochondrial membrane and neuronal axons, and on its similarity to potassium, with which it can exchange and compete to cause considerable disruption of fundamental cellular metabolism. For example, it has a ten-times greater affinity for membrane $\mathrm{Na}^{+}, \mathrm{K}^{+}$-ATPase than does potassium and alters the $\mathrm{pK}$ adversely. ${ }^{103}$ Thallium has also been reported to form insoluble intracellular complexes with riboflavin, which may account for symptoms mimicking deficiency of this vitamin (alopecia, dermatitis, neuropathy). ${ }^{104}$

\section{Clinical manifestations}

These are summarized in Table 7. The most characteristic feature is the hair loss which usually occurs $2-3$ weeks after the exposure.

\section{Laboratory investigation}

Initially, plasma electrolytes, renal function tests and full blood count may be quite normal. Measurement of thallium in urine and/or blood is necessary to confirm the diagnosis (see Table 8). Urinary concentrations are about ten-times greater than those in blood and since larger volumes are available, more can be extracted, so that better analytical performance can be achieved, e.g., between-run relative SDs 
TABLE 7. Clinical features and differential diagnosis of thallium poisoning

\begin{tabular}{|c|c|c|}
\hline \multirow[t]{4}{*}{ Symptoms } & $12-48 \mathrm{~h}$ & $\begin{array}{l}\text { Nausea, vomiting, diarrhoea, gastritis, duodenitis, pancreatic and parotid } \\
\text { damage }\end{array}$ \\
\hline & $2-5$ days & $\begin{array}{l}\text { Paraesthesiae, hyperaesthesia, headaches, respiratory depression, ptosis, } \\
\text { nystagmus, optic neuropathy and atrophy, myalgia, myopathy, severe pain, } \\
\text { loss of reflexes, convulsions, coma, delirium, acute motor neuropathy, } \\
\text { dementia and psychosis }\end{array}$ \\
\hline & $2-3$ weeks & Characteristic change at the bases of hair shafts, followed by loss of hair \\
\hline & $>3$ weeks & $\begin{array}{l}\text { Cardiac arrhythmias may occur for up to } 2 \text { months (due to autonomic } \\
\text { neuropathy or direct toxicity, or, in the case of sinus tachycardia, probably } \\
\text { secondary to increased catecholamine production.) Skin rash as in riboflavin } \\
\text { deficiency }\end{array}$ \\
\hline \multirow{2}{*}{$\begin{array}{l}\text { Differential } \\
\text { diagnosis }\end{array}$} & early & Gastroenteritis, myocardial infarction, alcoholism \\
\hline & later & $\begin{array}{l}\text { Guillain-Barré, systemic lupus erythematosis, diabetic polyneuritis, acute } \\
\text { intermittent porphyria, toxicity due to alcohol, arsenic, gold, mercury, } \\
\text { carbon monoxide, organophosphates }\end{array}$ \\
\hline
\end{tabular}

$<5 \% .{ }^{105}$ Measurement of thallium concentrations in blood and urine 2-3 times weekly are needed during the early stages of therapy, with monitoring of plasma potassium. Patients may be extremely unwell and complications which arise during the illness require careful biochemical monitoring.

For occupational monitoring, random urine samples are collected at the end of the working week to assess the internal dose, or after the weekend to assess the body burden. All samples are collected before the shift, to avoid contamination. Monitoring thallium exposure is important, because its long elimination time makes it, in effect, a cumulative poison.

\section{Therapy}

In the first $48 \mathrm{~h}$ after ingestion charcoal haemoperfusion or plasma exchange can reduce the amount of thallium available for the second, distribution, phase. Chelating agents are either not effective for elimination of thallium, or (e.g., in the case of sodium dithiocarbamate) will chelate the element but redistribute it to other tissues, particularly the CNS. However, because of the resemblance to potassium, there is a specific antidote. Oral potassium ferrihexacyanoferrate (Prussian blue, Berlin blue) is not absorbed from the gut. It sequesters thallous ions secreted into the intestine, by exchange with potassium ions from the molecular lattice, thus preventing the enteral recirculation of thallium. Concurrent intravenous infusion of potassium may help 'flush' thallous ions from tissue compartments, but given too early in treatment can accentuate intracellular thallium uptake. Treatment for long periods (months) may be required before thallium concentrations in blood and urine fall to acceptable values and complications such as sepsis, cardiac arrhythmias or respiratory failure can arise. Recovery from the neurological symptoms takes even longer and depends on good physiotherapy; full recovery of function may never be achieved.

\section{Case history 2: thallium poisoning}

Moore et al. described two cases of deliberate thallium poisoning. ${ }^{104}$ In the first patient, the symptoms commenced within 10 min of ingestion and were mistaken for myocardial infarction, gallstones or pancreatitis. In the second, serious symptoms resembling gastroenteritis

TABLE 8. Thallium reference values

\begin{tabular}{lll}
\hline & Reference interval & Toxic range \\
\hline Blood* & $<5 \mathrm{nmol} / \mathrm{L}(<1 \mu \mathrm{g} / \mathrm{L})$ & $>500 \mathrm{nmol} / \mathrm{L}(>100 \mu \mathrm{g} / \mathrm{L})$ \\
Urine & $<5 \mathrm{nmol} / \mathrm{L}(<1 \mu \mathrm{g} / \mathrm{L})$, or & $>1000 \mathrm{nmol} / \mathrm{L}(>200 \mu \mathrm{g} / \mathrm{L})$, or \\
(preferred) & $<1 \mathrm{mmol} / \mathrm{mol} \mathrm{creatinine}$ & $>100 \mathrm{nmol} / \mathrm{mol} \mathrm{creatinine}$ \\
& $(<1 \mu \mathrm{g} / \mathrm{g})$ & $(>100 \mu \mathrm{g} / \mathrm{g})$
\end{tabular}

*Heparinized sample, $10 \mathrm{~mL}$ in a plastic tube. 
developed within $1 \mathrm{~h}$. In both patients severe deterioration continued during the next 10 days, with loss of walking ability and development of hair loss suggesting the correct diagnosis. This was confirmed by thallium measurements and the patients were flown to a specialist Medical Toxicology Unit for treatment including psychotherapy and physiotherapy.

\section{MERCURY}

The most widely occurring mercury ore is cinnabar, or red mercuric sulphide. When ground, it yields vermilion, which has been much used in embalming. Five thousand years ago, it was used to preserve bones found in Dolmen tombs at La Velilla in Spain and this is believed to be the earliest recorded use of mercury as an antibacterial agent. ${ }^{105}$ Mercury compounds have since been used to treat many medical conditions. The death of Paganini may have been hastened by chronic mercury poisoning from the treatment he received for supposed syphilis and excessive use of laxatives containing calomel (mercurous chloride). ${ }^{106}$ Until 1953, the use of calomel in ointments for nappy rash and in teething powders led to the admission of many children to hospital for mercury poisoning (Pink disease). ${ }^{107}$ In 1978, when Yeh et al. described a fatal poisoning due to mercurochrome antiseptic used for a baby with a large omphalocoele, they reviewed 13 similar cases in the literature. ${ }^{108}$ In 1984, Laundy et al. described a fatal case of mercury poisoning resulting from irrigation of the peritoneal cavity with mercuric chloride after surgery for an ovarian tumour and reviewed ten similar cases from the literature. ${ }^{109}$

Mercury is one of the three major environmental metal poisons; as with lead, attention is currently focused on the risk of subtle damage caused by exposure to concentrations below those associated with detectable clinical effects. In particular, this concern relates to the degree and effects of exposure from dental amalgam. This matter has generated widespread concern and requests for mercury measurements by anxious patients.

Of the three classes of organic mercury, all have been used in agriculture and medicine. Alkyl compounds are by far the most toxic. Inorganic mercury compounds are classified according to their oxidation state (see Table 9). The different mercury species are linked through the environment in a complex and fascinating cycle. Elemental mercury is the principal atmospheric form. About half is generated from fossil fuels, mines, metal refineries, waste incinerators and crematoria, and the rest arises naturally through degassing of the earth's crust. Atmospheric mercury is oxidized to soluble divalent mercury and returns slowly to the earth in rainwater, having become distributed worldwide. In surface waters and sediments, divalent mercury can be reduced again, or methylated by micro-organisms to the highly toxic methylmercury. The half-life of this compound in fish is long and the bioaccumulation factor from water to edible fish can be more than $10^{7}$. Environmental methlymercury is therefore of concern in populations which depend on fish consumption, ${ }^{110,111}$ in which, although overt clinical symptoms have not been detected, concentrations of methylmercury in urine and blood overlap those found in people affected by accidental environmental contamination. One such disaster was the release into Minnamata Bay of waste methylmercury from an acetaldehyde plant during the 1950s. ${ }^{112}$ Other outbreaks of methylmercury poisoning occurred during the late 1960s, the most serious being in Iraq, where fungicide-treated wheat was used for food. Over 6000 people were affected and at least 600 died. Currently, there is evidence that mercury is accumulating in river sediments, farm animals and people living alongside rivers which drain gold mining sites in Brazil. ${ }^{113}$

Isolated poisonings are more likely to be caused by elemental or inorganic mercury. The metal is physically attractive and there are many recorded examples of children playing with it to the detriment of the whole family. Children occasionally swallow small photographic or hearing aid batteries which may contain as much as a gram of mercuric oxide. These often pass through the body unbroken, but must be monitored, because if the battery lodges in the stomach, acid disintegration of the casing can lead to serious poisoning. Mant et al. describe a 2-year-old child who needed two laparotomies to remove the battery and treat subsequent adhesions. ${ }^{114}$ Other important but occasional causes of mercury poisoning include ethnic remedies dispensed by Indian Hakim ${ }^{115,116}$ and cosmetics such as skin-lightening soaps containing mercuric iodide, which are banned in the European Community but available in other parts of the world. ${ }^{117,118}$ Poisoning has also been reported from mercury vapour released when fluorescent light bulbs are crushed ${ }^{119}$ and from the use of mercury in magical-religious ceremonies. ${ }^{120}$ 
TABLE 9. Mercury species and industrial uses

\begin{tabular}{lll}
\hline Main forms & Principal uses \\
\hline Inorganic & Elemental $\mathrm{Hg}^{0}$ & $\begin{array}{l}\text { Industrial, scientific and electrical instruments, gold- } \\
\text { refining, dentistry, chlor-alkali industry } \\
\text { Laxative, vermifuge, teething powders }\end{array}$ \\
& $\begin{array}{l}\text { Mercurous } \mathrm{Hg}(\mathrm{I}) \\
\text { (e.g., calomel, } \mathrm{HgCl})\end{array}$ & $\begin{array}{l}\text { Aercuric } \mathrm{Hg}(\mathrm{II}) \\
\left.\text { (e.g., corrosive sublimate, } \mathrm{HgCl}_{2}\right)\end{array}$ \\
Organic & $\begin{array}{l}\left.\text { Antic alkoxyalkyl (e.g., } \mathrm{CH}_{3} \mathrm{Hg}^{+}\right) \\
\text {Arger pulp, fungicides (now banned), diuretics, } \\
\text { preservatives }\end{array}$ \\
\hline
\end{tabular}

\section{Toxicokinetics}

\section{Inorganic mercury ${ }^{121}$}

At least $80 \%$ of elemental mercury $\left(\mathrm{Hg}^{0}\right)$ inhaled as vapour is absorbed. Curiously, prior ingestion of alcohol can reduce this to $50 \%$, because it inhibits oxidation of $\mathrm{Hg}^{0}$ to $\mathrm{Hg}$ (II) by catalase and hydrogen peroxide in erythrocytes. Absorption of the metal from the gastrointestinal tract is poor. About $10 \%$ of the $\mathrm{Hg}^{0}$ absorbed is distributed to the brain, and about $10 \%$ to the blood: most accumulates in the kidney. Excretion occurs equally in urine and faeces, with a small amount being exhaled. The half-lives in the blood (3 days) and brain (20 days) are shorter than in the whole body (58 days). Elemental mercury crosses the placenta freely.

Only $10-15 \%$ of ingested $\mathrm{Hg}(\mathrm{II})$ is absorbed. The half-life (48 days) in the body is longer than that for $\mathrm{Hg}^{0} . \mathrm{Hg}(\mathrm{I})$ is less well absorbed. In the body, both $\mathrm{Hg}^{0}$ and $\mathrm{Hg}(\mathrm{I})$ are oxidized to $\mathrm{Hg}$ (II). In this oxidation state mercury is highly reactive and can disrupt membranes, combine with sulphydryl groups to inhibit enzymes and damage DNA. This may prove to be the common mechanism for the toxic effects of all mercury species; apparent variations only reflecting differences in absorption and distribution. The kidney is the target organ for $\mathrm{Hg}$ (II), which becomes concentrated in the proximal renal tubules as various solutes are reabsorbed from the glomerular filtrate. It causes severe damage to the brush border membranes, with mitochondrial and lysosomal damage, particularly on the S3 segment of the proximal tubules. Selenium in the kidney can combine with mercury to form crystalloid inclusion bodies, and MT is induced by mercury. These mechanisms may be protective. ${ }^{122}$ After recovery from the acute effects of poisoning, mercury may be detectable microscopically within tissues for many years.

\section{Organic mercury}

In contrast, about $90 \%$ of most organic mercury compounds is absorbed from the intestine, and phenylmercury is also absorbed through the skin. Fig. 5 shows the inter-relationship of mercury species. Much is known about organic (particularly methyl) mercury from studies conducted in the wake of environmental accidents. This has been well reviewed by Clarkson. ${ }^{123}$ Methylmercury takes about $30 \mathrm{~h}$ to equilibrate in the blood compartment and rather longer in the brain. Equilibration with tissues occurs more rapidly than excretion so that ratios of methylmercury concentrations between tissues remain constant. In primates, probably including humans, the ratio between brain (the target organ) and blood mercury concentrations is $5: 1$, higher than that in other species. The hair:blood ratio is about 250:1. Blood and hair measurements can therefore be used to estimate internal dose to the critical organ. Both have been used to establish thresholds for the onset of various symptoms.

Although most textbooks state that methylmercury enters the brain and cells because it is lipid-soluble, only the chloride $\left(\mathrm{CH}_{3} \mathrm{HgCl}\right)$ is lipophilic. Other derivatives form hydrophilic compounds through thiol groups in proteins and amino acids. Recent studies suggest that methylmercury, when combined with cysteine, has a structure which resembles methionine and enters brain and other cells via the neutral amino acid carrier. Other studies in rats have shown that intracellular methylmercury, complexed with glutathione, leaves hepatocytes via the glutathione carrier and is secreted into the bile. Reabsorption of the complex occurs in the gall bladder and intestine, but any organic mercury reaching the lower intestine is demethylated by bacteria to $\mathrm{Hg}(\mathrm{II})$. The central nervous system is the target organ for methylmercury toxicity and, 


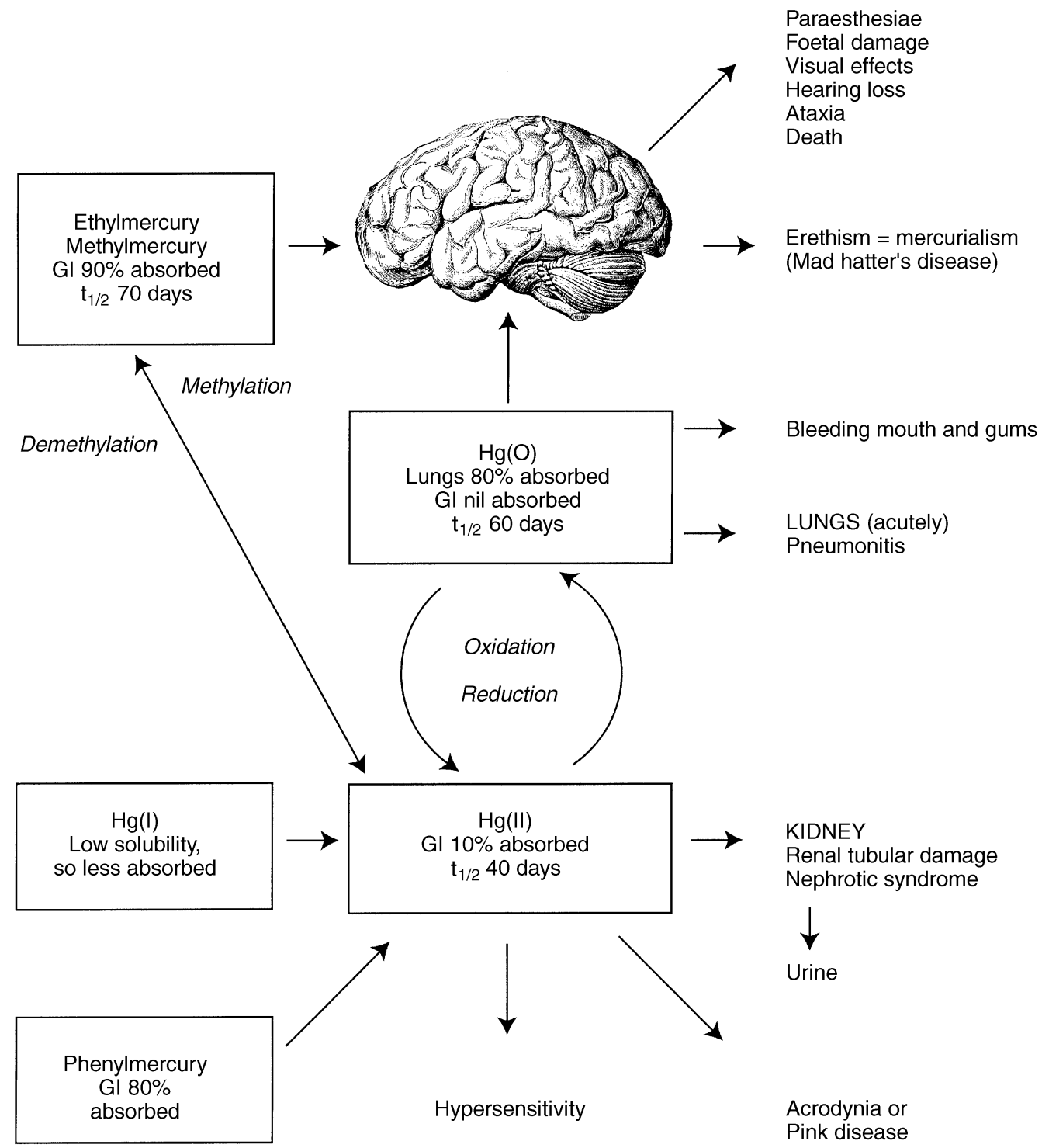

FIGURE 5. Mercury: some interactions and effects of the different chemical species within the body. GI=gastrointestinal.

in adults, the visual cortex and granular layer of the cerebellum are particularly vulnerable. Methylmercury crosses the placenta freely and has devastating effects on the foetal brain. The critical effect is inhibition of the polymerization of microtubules, a process essential for the cell division and neuronal migration crucial to normal development of the foetal brain. Effects in both adults and foetuses are dose-related, but the foetus is $5-10$ times more sensitive.
In recent years it has been suggested that a number of illnesses with poorly defined symptoms, such as multiple sclerosis and Alzheimer's disease, are related to mercury released from amalgam fillings. ${ }^{124}$ Studies measuring mercury in oral air and eluates from various types of amalgam in vitro have indeed shown that mercury is released from these fillings. Estimates of the mean amounts released vary but are up to $20 \mu \mathrm{g}$ per day, according to the amalgam type 
and number of surfaces (World Health Organization recommended maximum intake in adults is $45 \mu \mathrm{g} /$ day $\left.^{125}\right)$. The amount released is increased after insertion or removal, by chewing gum and grinding the teeth. ${ }^{126,127}$ Blood and urine mercury concentrations are higher in subjects with amalgam fillings and indicate that after fish, these are the main source of mercury in the general population. ${ }^{128}$ One study of tissue mercury in autopsy samples from patients with multiple sclerosis showed less mercury in the brain than in control samples, ${ }^{129}$ while Fung et al. showed no differences in blood or brain mercury concentrations, or mercury:selenium ratios in patients with Alzheimer's disease in comparison with controls. ${ }^{130,131}$

However, it must be emphasized that: (a) the amounts of mercury released and absorbed are small; (b) blood and urine concentrations generally found are considerably lower than the maximum limits currently accepted as safe for occupationally exposed people; (c) these limits may not necessarily be relevant if newer toxic effects are under consideration; (d) analytical methods in general use cold vapour atomic absorption and may not be sufficiently sensitive unless they include a prior concentration step; and (d) good control groups are difficult to establish for such studies. The possible harmful effects of mercury from amalgam have recently been comprehensively reviewed by Eley. ${ }^{132}$

The final conclusion remains uncertain, but it seems likely that a few people with corroded fillings may develop blood or urine mercury concentrations comparable with occupational limits and some who have certain oral conditions may benefit from replacement of amalgam fillings. ${ }^{133}$ An even smaller group of people, in whom the smallest trace of mercury, (e.g., in fillings, shampoos, contact lens fluids) may lead to contact dermatitis, gingivitis or oral lichen planus, suffer from true hypersensitivity to mercury, which can be confirmed by patch testing. ${ }^{134,135}$

Mercury affects haem synthesis in renal tissue leading to porphyrinuria. One group in the USA, ${ }^{136}$ in a study of dentists exposed to significant amounts of mercury in their surgeries, has shown a correlation between urinary coproporphyrin, behavioural deficits and mercury excretion after a test dose of DMPS. In vitro studies with various blood cells reveal a host of toxic effects of mercury, including increased numbers of chromatid breaks, micro- nuclei formation, reductions in B cell proliferation and immunoglobulin synthesis. ${ }^{137-140}$ Other studies have failed to demonstrate differences in circulating antibodies, or complement components, at least at low exposure. ${ }^{141}$

\section{Clinical manifestations}

Exposure to high concentrations of mercury vapour affects primarily the lungs, causing pleuritic pain and shortness of breath, and also fever, lethargy, nausea, vomiting and blurring of the vision, within hours of exposure. The lungs show bronchiolitis with interstitial infiltrates, and pulmonary function tests indicate restrictive changes with reduced diffusion capacity. Levin et al. reported four young men who attempted to purify South American gold at home using mercury. ${ }^{142}$ Their urinary excretions of mercury ranged from $0 \cdot 85-2.50 \mu \mathrm{mol} / 24 \mathrm{~h}(170-500 \mu \mathrm{g} /$ $24 \mathrm{~h}$ ) on presentation. One suffered a cough and shortness of breath, two required hospitalization for treatment with penicillamine and one needed intensive care. Less severe exposure to mercury vapour affects the brain and nervous system. Symptoms include excessive shyness, intolerance, irritability, gingivitis, paraesthesiae (all occurring early), salivation, metallic taste, stomatitis, tremor, marked weight loss, memory loss, myalgia, muscle spasms, arthralgias, night sweats, insomnia and hallucinations. The term 'erethism' was first coined by Pearson in 1805 to describe all these effects, ${ }^{143}$ but now is used to refer only to the early group. The non-specificity of these clinical features and their insidious, delayed appearance means that the diagnosis may be missed unless a careful history is taken. They may continue to increase in severity even after exposure has ceased.

Metallic mercury has been injected directly into tissues or veins, by accident from catheter tips or during arterial gas sampling, and sometimes intentionally. ${ }^{144-146}$ Mercury occludes small capillaries, and causes pleuritic pain, emboli and transient ischaemia as presenting features. Sometimes sterile abscesses form which exude droplets of mercury and, rarely, the resulting inflammation can provoke more widespread distribution of mercury and systemic poisoning. Mercury persists in the body for many years, giving a speckled appearance to radiographs. Ingested metallic mercury (e.g., from broken clinical thermometers) may pass through the intestine uneventfully or become entrapped leading to complications such as fistulae. ${ }^{147}$ 
Mercuric chloride (corrosive sublimate) is exceedingly toxic in all metabolic systems. Ingested in large quantities it causes severe necrosis throughout the gastrointestinal tract, with cardiovascular shock and acute renal failure. In smaller amounts it may cause patients to present with unexplained loss of weight, diarrhoea, renal failure and neurological signs such as paraesthesia and tremor. 'Acrodynia' or 'Pink disease' is a further syndrome of mercury toxicity, found in certain individuals, which may be caused by stimulation of the sympathetic nervous system. It was formerly associated with the use of medications containing calomel, but may occur with other types of exposure (see Case history 3). The hands and feet become red, peeling and painful, there is loss of weight, irritability and marked personality change, hypertension, excessive paroxysmal sweating with photophobia in more severe cases. Some of these effects may be due to increased circulating catecholamines, and acrodynia has been confused with phaeochromocytoma. ${ }^{148}$

Methylmercury exhibits an extremely long latent period. The earliest symptoms are paraesthesia, malaise and blurring of the vision. More severe exposure leads to constriction of the visual fields, deafness, dysarthria, ataxia and, finally, mental derangement, coma and death. Exposure in utero results in microcephaly and even more severe brain damage. Many nonalkyl organic mercurials are virtually without toxic effects, except phenylmercury which is converted to $\mathrm{Hg}$ (II) and shows similar toxicity. The potential overlap of syndromes caused by the different mercury species is shown in Fig. 5 and is well illustrated in the family described below.

\section{Case history 3: mercury poisoning \\ $(\mathrm{McNeil} \text { et al. })^{149}$}

An 8-year-old boy found some metallic mercury which he took home and spilt. He remained well throughout, but 2 months later, his 14-year old sister presented with painful, discoloured, hot feet. She was agitated and uncooperative, and was found to have raised blood pressure and proteinuria. The father also developed acrodynia with variable proteinuria, but no amino aciduria or glycosuria. The mother had had a transient rash initially and amino aciduria at the time of diagnosis; about 3 weeks later she developed oedema with $10 \mathrm{~g}$ proteinuria per day. All members of the family had a complete recovery, including the sister whose 'difficult' behaviour (characteristic of erethism) improved dramatically as her mercury level declined.

\section{Laboratory investigations}

The diagnosis of mercury poisoning is based on demonstrating concentrations higher than the limits shown in Table 10 for either whole blood or urine (early morning or $24 \mathrm{~h}$ collection). Urine is easier to measure although there may be problems from skin contamination, mercurial preservatives in disposable equipment and losses due to adsorption or diffusion if stored in polythene containers. Also, because of effects of mercury on mood and personality, urine collections may be unreliable for monitoring therapy and blood samples are preferable. Hair analysis is seldom of value in individual cases, unless it is important to estimate the pattern of exposure with time. It is analytically possible to measure total and inorganic mercury separately in blood or urine and this is occasionally helpful. Mercury excretion after a test dose of the chelating agent DMPS may reflect the body burden better than basal excretion, but has not found wide application. Urinary mercury reflects exposure during the previous $2-3$ months; blood mercury with its shorter half-life reflects exposure in the preceding week. Either may be used for occupational monitoring, depending on the task. Measurement of urinary coproporphyrin is not generally of diagnostic value.

In patients presenting with fever following acute exposure to high levels of $\mathrm{Hg}^{0}$, measurement of blood gases will reveal hypoxaemia; following acute ingestion of $\mathrm{Hg}(\mathrm{II})$ salts there may be signs of developing cardiovascular collapse and acute renal failure. With lesser ingestion, renal failure may be the presenting feature. Otherwise, 'routine' biochemical tests are likely to be normal although increased serum bilirubin and alanine aminotransferase have been reported in individuals with prolonged high exposure to mercury compounds. Amino aciduria, glycosuria and phosphaturia may or may not be present and there may be increased excretion of tubular proteins. Urine should be tested for protein in case a nephrotic picture develops, in which case the serum albumin will also decline.

\section{Therapy}

In the past dimercaprol and later oral penicillamine have been used as chelating agents to treat poisoning from all mercury species. The new oral agent DMPS is proving more effective in 
TABLE 10. Mercury reference values

\begin{tabular}{lll}
\hline & Blood* & Urine $^{\dagger}$ \\
\hline Unexposed persons & $\begin{array}{l}<0 \mathrm{nmol} / \mathrm{L} \\
<4 \mu \mathrm{g} / \mathrm{L}\end{array}$ & $\begin{array}{l}<50 \mathrm{nmol} / 24 \mathrm{~h}(<10 \mu \mathrm{g} / 24 \mathrm{~h}), \\
\text { or }<5 \mathrm{nmol} / \mathrm{mmol} \\
\text { creatinine }(<10 \mu \mathrm{g} / \mathrm{g})\end{array}$ \\
Dental workers & $\begin{array}{l}<10 \mathrm{nmol} / \mathrm{mmol} \\
\text { creatinine }(<20 \mu \mathrm{g} / \mathrm{g})\end{array}$ \\
Industrial workers & $\begin{array}{l}<5 \mathrm{nmol} / \mathrm{mmol} \\
\text { creatinine }(<90 \mu \mathrm{g} / \mathrm{g})\end{array}$ & $\begin{array}{l}\text { Organic }<15 \mathrm{nmol} / \mathrm{mmol} \\
\text { creatinine } \\
\text { Inorganic }<120 \mathrm{nmol} / \\
\text { mmol creatinine }\end{array}$ \\
\hline
\end{tabular}

*Lithium heparin or ethylenediaminetetra-acetic acid (EDTA) whole blood, $10 \mathrm{~mL}$ in a hard plastic or glass tube.

$\dagger 24 \mathrm{~h}$ collection in a hard plastic bottle washed with nitric acid, or an early morning sample in a sterile universal.

eliminating mercury and can reduce the half-life to about 11 days. ${ }^{150,151}$ The need for treatment can be difficult to assess; the value of early treatment, the risk of progression and late onset of symptoms must be balanced against wide individual susceptibility. Patients with injected mercury metal are monitored using blood mercury concentration and tests of renal function. Recovery from acute poisoning may be complete.

\begin{abstract}
ARSENIC
After lead and mercury, arsenic is the third major environmental poison. Like them it occurs naturally in the environment; contamination of groundwater with inorganic arsenic (in Taiwan, northern Chile and most recently in West Bengal) gives rise to endemic arseniasis. ${ }^{152-154}$ Man's activities in smelting gold, copper and zinc, and making pesticides and fertilizers, have caused pollution with arsenic as well as with lead and mercury, and like these metals arsenic has frequently been used in Western medicine; Fowler's solution of $1 \%$ arsenic trioxide was formerly used for treating leukaemia, psoriasis and asthma, and as a tonic. The use of inorganic arsenical preparations is no longer recommended. Like lead and mercury, the use of arsenic in Ayurvedic medicines dispensed by unqualified Hakims is continuing to give rise to reports of sporadic poisonings. These are worrying particularly because the number reported probably understates the problem. ${ }^{115}$
\end{abstract}

\section{Toxicokinetics}

Ingested inorganic salts are well absorbed, depending on their solubility and other dietary factors. More soluble salts may also be absorbed following inhalation and through the skin. Organic arsenic compounds are almost completely absorbed. In the body, arsenic is distributed rapidly to lungs, liver, kidney and spleen, after which it is redistributed to the skin, nails and hair, where it binds tightly to keratin. The halflife varies with the tissue, being longest in the skin and lungs. The kinetics of excretion, through the kidneys, suggests a three-compartment model. ${ }^{155}$

Arsenic exists as a number of species and oxidation states having marked differences in toxicity:

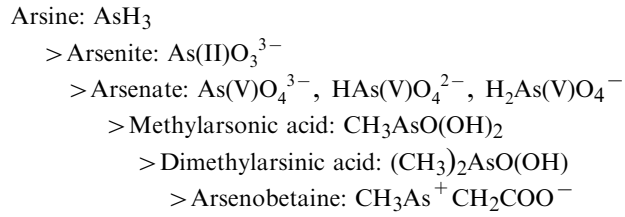

Arsine, the gaseous hydride, is rapidly absorbed through the lungs and acts by disrupting erythrocyte sodium-potassium pumps, causing haemolysis. Arsine is usually liberated accidentally; the best known example being the leakage of a canister of the gas into the hold of a ship, which resulted in eight of the crew being poisoned. ${ }^{156}$ The most severely affected crew-member presented with a haematocrit of $0 \%$ !

Arsine poisoning is rare; arsenite is the most important toxic agent. The adverse effects are widespread, particularly affecting the gastrointestinal, cardiovascular and renal systems and, in the longer term, the peripheral and central nervous systems. Arsenic metabolism varies 
between species; in humans, reduction and methylation take place in the liver to generate much less toxic organic arsenic compounds:

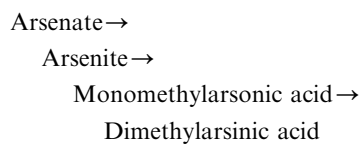

Arsenic excreted in urine consists of $10-15 \%$ inorganic arsenic, 10-15\% monomethylarsonic acid and $60-80 \%$ dimethylarsinic acid. In fish and shellfish there is further metabolism to trimethylarsine and other organic species, including arsenobetaine. Arsenobetaine is a stable and non-toxic compound. It is rapidly absorbed from the human intestine and excreted unchanged in urine.

Inorganic arsenic species are large ligands and some of their toxicity resides in a tendency to combine preferentially with the sulphydryl groups of proteins. In addition, they have certain specific reactions. The arsenite oxyanion has a pyramidal structure, such that it can form a stable ring with the alpha-lipoic acid moiety of pyruvate dehydrogenase, causing inhibition and raised pyruvate concentrations. Because the stereochemical structure of the arsenate oxyanion resembles that of sulphate and phosphate, arsenate can enter mitochondria and compete with phosphate as a substrate to form high energy compounds, but the arsenic analogues are not stable (Fig. 2) and so uncouple oxidative phosphorylation. ${ }^{157}$ Arsenic can cross the placenta easily and is excreted in breast milk.

\section{Clinical manifestations}

Taken acutely, arsenic can cause vomiting and haemorrhagic diarrhoea within minutes, or hours if the poison is taken with food; haematuria and acute renal failure may follow. If the poisoning takes place over a longer period abdominal pain, facial oedema, upper respiratory tract difficulty and/or obstructive jaundice with hepatomegaly can develop. Over about 3 weeks anorexia and features of neuritis develop (weakness, salivation, trembling, loss of tendon reflexes, impaired cutaneous sensation), sometimes after the arsenic ingestion has stopped. ${ }^{158}$ Transverse white 'Mees' lines appear in the nails. Milder poisoning causes similar but milder symptoms. In a 68-year-old man with prolonged exposure to an arsenical insecticide the main features were of persistent neuropathy, macrocytosis without anaemia and hyperkeratosis. ${ }^{159}$

Occupational exposure to arsenic is associated with dermatitis and skin and nasal ulcers, caused by the corrosive action of inorganic salts. There is an increased incidence of peripheral neuropathy, cardiovascular disease, cirrhosis and renal tubular impairment. Those living in areas with contaminated groundwater develop hyperkeratosis, pigmentation and ulcers after 2 or 3 year's exposure. The incidence of cancers of skin, lung and gastrointestinal tract is increased. ${ }^{160}$

\section{Laboratory investigation}

Arsenic can be measured in whole blood or urine, but the latter is to be preferred. The identification of stable non-toxic arsenic species, such as arsenobetaine, derived from dietary seafood is more difficult than measurement of total arsenic, but their presence can make the confirmation of arsenic poisoning from total arsenic measurements difficult. A single meal of seafood can raise the excretion of total urinary arsenic more than 50 times. If arsenic is measured without prior digestion, inorganic arsenic and the two acids are measured, but arsenobetaine arsenic is not. Some increase in monomethylarsonic and dimethylarsinic acids may arise from the metabolism of other organic species in seafood, e.g., arsenosugars from seaweed. ${ }^{161,162}$ Seafood should be omitted for 5 days before samples are collected. If this is not possible, information concerning intake is helpful. If the total urinary arsenic is raised an approximate separation into non-toxic organic and toxic inorganic arsenic can be achieved by measuring the arsenic with and without prior digestion. For more rigorous speciation, complex methods based on HPLC to separate the individual forms of arsenic are available in a few centres.

Table 11 shows reference ranges for blood and urine arsenic. Hair analysis is valuable for forensic purposes and in surveying exposed populations. ${ }^{163}$ For occupational monitoring, urine should be collected towards the end of the working week.

\section{Therapy}

Because of the affinity of inorganic arsenic for sulphydryl groups, chelation with dimercaprol has been used to treat arsenic poisoning. Penicillamine has also been used, but may be less effective at promoting excretion. ${ }^{161}$ 
However, DMPS has been used in several cases, e.g., in two patients who ingested grams of arsenic trioxide, mistaken for a substance of abuse: they made a full recovery. ${ }^{164}$ The symptoms of peripheral neuropathy are not always reversible.

\section{ANTIMONY}

Antimony has come to prominence during recent years, as a consequence of an hypothesis that a fungus (Scropularis brevicaulis), identified in PVC mattresses used by babies who died of sudden infant death syndrome (SIDS), acted on fire retardant compounds containing antimony, arsenic or phosphorus to form poisonous hydride gases ('Cook Report'. Cot death (poisonings). Central Television, 17 November 1994). This hypothesis was supported by the finding of higher blood antimony concentrations in samples from SIDS babies than in those who had died from other causes. ${ }^{165}$ Correspondence in The Lancet and editorials in the British Medical Journal have followed. ${ }^{166-169}$ The original work has been repeated with the inclusion this time of essential control experiments. ${ }^{170}$ This has shown that the fungus $S$. brevicaulis was not present on all the mattresses. Mercuric iodide and silver nitrate test papers (as used in the first study) gave colour responses whenever any bacterial growth occurred, possibly due to the presence of sulphur compounds. No antimony, arsenic or phosphorus could be detected in the mattresses using a variety of methods.

Antimony is used in glass, paint and in the ceramics, printing, explosives and semiconductor industries. Its compounds are used as fire retardants and the sulphide is used in medical scintigraphy. Antimonials are used for treating schistosomiasis (bilharzia) and the more resistant cutaneous and visceral forms of leishmaniasis (kala-azar) and may give rise to toxicity.

\section{Toxicokinetics}

Antimony is in the same group (Va) of the periodic table as arsenic, but is heavier. Its range of chemical forms is similar, as are their properties and biological effects, although the antimonials are slightly less toxic. Following the concerns about antimony in babies, studies on infants' urine have shown a variable but low excretion which is slightly higher in pre-term babies. There was no correlation with urine cotinine, suggesting that tobacco and passive smoking are not an important source of exposure to antimony. ${ }^{171}$

\section{Clinical manifestations}

The hydride gas stibine $\left(\mathrm{SbH}_{3}\right)$ is the most toxic form and causes headache, nausea, vomiting, jaundice and anaemia. Acute exposure to other antimonials affects the skin and causes hair loss and weight loss. Damage to heart, liver and kidney may be found and myocardial infarction is possible. Pentavalent compounds are less toxic than trivalent antimonials and are preferred for therapeutic use. Chronic exposure leads to skin problems, with antimony spots, irritation and dermatitis. ${ }^{172}$

\section{Laboratory investigations and therapy}

Measurement of antimony in urine is used for occupational monitoring and in EDTA blood samples for therapeutic monitoring or suspected toxicity. Reference values are shown in Table 12. For treatment, the agent of choice would be DMPS but it has proved possible to manage patients who have had blood antimony concentrations as high as $820 \mathrm{nmol} / \mathrm{L} \quad(100 \mu \mathrm{g} / \mathrm{L})$ following acute exposure without chelation.

\section{BISMUTH}

This element has a few industrial uses in pigments, ceramics, and low-melting alloys. As the chelate tripotassium dicitratobismuthate, it has recently become important in the triple

TABLE 11. Arsenic reference values

\begin{tabular}{lll}
\hline & Blood $^{*}$ & Urine \\
\hline Unexposed persons & $<130 \mathrm{nmol} / \mathrm{L}(<10 \mu \mathrm{g} / \mathrm{L})$ & $<130 \mathrm{nmol} / 24 \mathrm{~h}(<10 \mu \mathrm{g} / 24 \mathrm{~h})$, or \\
& & $<40 \mathrm{nmol} / \mathrm{mmol} \mathrm{creatinine}(<3 \mu \mathrm{g} / \mathrm{g})$ \\
Occupational monitoring & & $<230 \mathrm{nmol} / \mathrm{mmol} \mathrm{creatinine}$ \\
& & $(<17 \mu \mathrm{g} / \mathrm{g})$ \\
\hline
\end{tabular}

NB Seafoods cause greatly increased values and are best omitted for 5 days prior to sampling. ${ }^{*}$ Ethylenediaminetetra-acetic acid (EDTA) whole blood, $10 \mathrm{~mL}$ in a plastic tube. ${ }^{\dagger}$ Random urine samples collected towards the end of the working week. 
therapy against Helicobacter pylori in patients with gastric or duodenal ulcers. It is a wellknown over-the-counter remedy for indigestion and constipation.

\section{Toxicokinetics and clinical manifestations}

Bismuth resembles lead and mercury in forming nuclear inclusion bodies in renal cells and, in common with gold and mercury, can cause development of a nephrotic syndrome. In the mid-1970s a number of patients taking very large doses developed an encephalopathy which proved to be reversible. Thomas et al. ${ }^{173}$ showed that some patients absorb considerably more bismuth than others and maintain high blood and urine concentrations, although renal clearance is normally rapid at low blood concentrations. The effect does not seem to be dose-related as some patients with high blood concentrations do not get encephalopathy.

\section{Laboratory investigations and therapy}

Bismuth can be measured in blood or urine. Because it is normally rapidly excreted in urine there is a greater risk of higher blood concentrations and consequent problems in patients with renal impairment (see Case history 4). Reference values are shown in Table 12. When treatment is necessary, a chelating agent can be used.

\section{Case history 4: bismuth poisoning}

(Playford et al. $)^{174}$

A patient with poor renal function (creatinine clearance $15 \mathrm{~mL} / \mathrm{min}$ ) who was being treated with bismuth developed encephalopathy after taking twice the recommended dose for 2 months. He was given a course of DMPS. Bismuth clearance increased from $0 \cdot 24$ to $2.4 \mathrm{~mL} / \mathrm{min}$; after 50 days, blood bismuth concentration had fallen from $4 \cdot 21$ to $0 \cdot 22 \mu \mathrm{mol} / \mathrm{L}$ (from 880 to $46 \mu \mathrm{g} / \mathrm{L}$ ).

\section{TIN}

Tin has uses in the tinplate, container and paint industries and as a stabilizer of plastics. Tin fluoride is used in toothpaste. Inorganic tin salts are seldom toxic, but as with lead, organotin compounds are more toxic. They are widely used as biocides in agriculture and as anti-fouling agents in marine paints. Tributyltin is the best known. Environmental pollution of rivers and estuaries from this source is increasingly recognized as is contamination from factories making the agricultural biocides. ${ }^{175}$

\section{Toxicokinetics}

Inorganic tin is an inducer of haem oxygenase. However, tin metalloporphyrin inhibits this enzyme and has been tested, as have several other metalloporphyrins, as therapeutic agents in reducing haem conversion to bilirubin in several clinical situations, e.g., Crigler-Najjar syndrome, acute hepatic porphyria and neonatal jaundice.

In the body tetraethyl- and tetramethyltin, like the organic lead equivalents, are dealkylated rapidly to toxic trialkyl derivatives and are then metabolized more slowly to the less toxic di- and mono-derivatives which are less toxic. ${ }^{15}$ Organotin compounds are genotoxic: dibutyltin is the most toxic compound in this respect.

\section{Clinical manifestations}

Tin hydride is a neurotoxic gas but, unlike arsine, it does not cause haemolysis. Severe irritation and burning occurs if skin is exposed to organic tin, which may be absorbed and lead to systemic features including anaemia and renal and hepatocellular damage. Triethyltin uncouples oxidative phosphorylation, causing mitochondrial damage, and causes cerebral oedema leading to neurotoxicity. Organotin compounds may stimulate catecholamines

TABLE 12. Reference values for antimony, bismuth, tin

\begin{tabular}{lll}
\hline & Blood (or serum) & Urine \\
\hline Antimony* & $2 \cdot 5-28 \cdot 7 \mathrm{nmol} / \mathrm{L}(0 \cdot 3-3 \cdot 5 \mu \mathrm{g} / \mathrm{L})$ & $1 \cdot 6-18 \mathrm{nmol} / \mathrm{L}(0 \cdot 2-2 \cdot 2 \mu \mathrm{g} / \mathrm{L})$ \\
Bismuth* & $<0 \cdot 5 \mathrm{nmol} / \mathrm{L}(0 \cdot 1 \mu \mathrm{g} / \mathrm{L})$ & $3 \cdot 8-7 \cdot 7 \mathrm{nmol} / \mathrm{L}(0 \cdot 8-1 \cdot 6 \mu \mathrm{g} / \mathrm{L})$ \\
$\quad$ Therapeutic & $\mathrm{Up} \mathrm{to} 240 \mathrm{nmol} / \mathrm{L}(50 \mu \mathrm{g} / \mathrm{L})$ & \\
Warning range & $240-480 \mathrm{nmol} / \mathrm{L}(50-100 \mu \mathrm{g} / \mathrm{L})$ & \\
Toxic & $>480 \mathrm{nmol} / \mathrm{L}(100 \mu \mathrm{g} / \mathrm{L})$ & $<0 \cdot 22 \mu \mathrm{mol} / \mathrm{L}(<26 \mu \mathrm{g} / \mathrm{L})$ \\
Tin $^{\dagger}$ & $<0 \cdot 25 \mu \mathrm{mol} / \mathrm{L}(30 \mu \mathrm{g} / \mathrm{L})$ & \\
\hline
\end{tabular}

*Ethylenediaminetetra-acetic acid (EDTA) whole blood, $2 \mathrm{~mL}$ in a plastic tube. ${ }^{\dagger} \mathrm{Serum}, 2 \mathrm{~mL}$ in a plastic tube. 
leading to hyperglycaemia, changes in blood pressure and immunotoxicity. ${ }^{176}$

\section{Laboratory investigations}

Urinary excretion of tin is suitable for monitoring occupational exposure to inorganic tin species, together with haematological indices. Techniques for the speciation of organic tin using gas chromatography with mass spectrometry are available, ${ }^{177}$ but measurement of total tin in blood or urine can provide adequate indication of recent exposure. Reference values are shown in Table 12, although these are based only on the small number of reports available.

\section{CONCLUSION}

The widespread effects of poisoning by metals makes this difficult to identify if exposure is not readily apparent. There are a few presentations which suggest specific elements, for example the characteristic hair loss within thallium, the hepatic effects of arsenic and the renal effects of mercury. Much also depends on the degree and duration of exposure. The effects of lead poisoning with low exposure is a matter of major concern. The solution should lie in public health measures to manage the lead content of water supplies and effective abatement procedures to deal with old leaded paint. Nevertheless, children can still present as acute medical emergencies requiring urgent treatment to avoid lead encephalopathy and its long-term sequelae. The importance of taking a careful history, including questions to identify any non-prescribed supplements, cannot be over-emphasized. The possibility that more than one metal may be present should not be overlooked: for example, lead and arsenic can occur on demolition sites, mercury and arsenic in old waste landfill sites, and combinations of features of mercury, lead and arsenic poisoning have been found in patients using Asian remedies. ${ }^{16,178}$

In addition to poisoning from the metals discussed, new problems are constantly arising: technological developments in medicine may lead to toxicity, in some cases because the body's normal defences are by-passed e.g., aluminium in renal failure and parenteral nutrition, manganese in parenteral nutrition and silicone in breast implants (although the effects of this remain unproven and the silicone compound rather than silicon itself is implicated). ${ }^{179}$ The newest concern relates to the possible effect of wear debris from metal joint prostheses, which have been shown to accumulate in lymph nodes. Nutritional supplements are also potential source of problems: in at least one case, excessive use has been partly responsible for copper overload and liver failure (O'Donoghue, personal communication); the sale of germanium-containing supplements was eventually banned because of the risks of renal toxicity.

\section{Acknowledgements}

We would like to acknowledge the help received as a result of the generous spirit of scientific exchange which exists among DB's colleagues on the SAAS Trace Element Sub-Committee: Drs Braithwaite, Delves, Fell, Halls, Taylor, Walker, White and Widdop and Messrs House, Newton and Sheehan. In particular, Dr Andrew Taylor has helped with many queries and provided valuable criticism on early drafts of the manuscript. We also thank the members of CLISC for their patience and enthusiasm during the preparation of this review, and for their invaluable comments.

\section{REFERENCES}

1 Health and Safety Executive Annual Report: Statistical Supplement 1992-93. London: HMSO, 1993

2 Braithwaite RA, Girling AJ. Bovine reference materials for accuracy control of blood lead analysis. Fresenius $Z$ Anal Chem 1988; 332: 704-9

3 Water Pollution at Lowermoor North Cornwall. Report of the Lowermoor Incident Health Advisory Group. Truro: Cornwall and Isles of Scilly District Health Authority, 1989

4 Identification and control of pollutants of broad international significance. Document A/CONF. 48/ 8 prepared for the United Nations Conference on the Human Environment. Stockholm, 1972

5 World Health Organization. Environmental Health Criteria 3. Lead. Geneva: WHO, 1977

6 Nordberg GF. Application of the 'critical effect' and 'critical concentration' to human risk assessment for cadmium. IARC Sci Publ 1992; 118: 3-14

7 Control of Lead at Work. Approved Code of Practice. London: HMSO, 1985

8 Control of Lead at Work Regulations 1998. London: The Stationery Office Ltd, 1998

9 Clarkson TW. Molecular targets of metal toxicity. In: Brown SS, Savory J, eds. Chemical Toxicology and Clinical Chemistry of Metals. London: Academic Press; 1983: 217-26

10 Chisholm JJ, Barltrop D. Recognition and management of children with increased lead absorption. Arch Dis Child 1979; 54: 249-62

11 El-Sharkaw AM, Morgan WD, Cobbold S, Jaib MB, Evans CJ, Somervaille LJ, et al. Unexpected 
mobilisation of lead during cisplatin therapy. Lancet 1986; ii: $249-50$

12 Silbergeld EK, Sauk J, Somerman M, Todd A, McNeill F, Fowler B, et al. Lead in bone; storage site, exposure source and target organ. Neurotoxicology 1993; 142-3: 225-36

13 Coyle P, Philcox JC, Rofe AM. Clinical significance of metallothionein: a dealer in heavy metals. Clin Biochem Revs 1993; 14: 118-25

14 Shelton KR, Egle PM, Bigbee JW, Klann E. A nuclear matrix protein stabilised by lead exposure: current knowledge and future prospects. Neurotoxicology 1993; 14: 61-8

15 Mushak P. Mammalian biotransformation processes involving various toxic metalloids and metals. In: Brown SS, Savory J, eds. Chemical Toxicology and Clinical Chemistry of Metals. London: Academic Press, 1983: 227-45

16 Graziano JH, Leong JK, Friedheim E. 2,3Dimercaptosuccinic acid: a new agent for the treatment of lead poisoning. $J$ Pharmacol Exp Ther 1978; 206: 696-700

17 Glotzer DE. The current role of 2,3-dimercaptosuccinic acid (DMSA) in the management of childhood lead poisoning. Drug Safety 1993; 9: 85-92

18 Rey-Alvarez S, Menke-Hargrave T. Deleading dilemma: pitfalls in the management of childhood lead-poisoning. Paediatrics 1987; 79: 214-17

19 Shiwen C, Yin Y, Zhineng H, Xiangu Z, Zhadu Y, Huidong L, et al. Cadmium exposure and health effects among residents in an irrigation area with ore dressing wastewater. Sci Total Environ 1990; 90: $67-73$

20 Buchet JP, Lauwerys R, Roels H, Bernard A, Bruaux P, Claeys F, et al. Renal effects of the cadmium burden of the general population. Lancet 1990; 336: 699-702

21 Herber RFM. The World Health Organisation study on health effects of exposure to cadmium: morbidity studies. IARC Sci Publ 1992; 118: 347-58

22 Friberg LT, Piscator M, Nordberg GF. Occurrence, possible routes of exposure and daily intake. In: Weast RC, ed. Cadmium in the Environment. Cleveland: CRC Press, 1971

23 Buckler HM, Smith WDF, Rees WDW. Self poisoning with oral cadmium chloride. $B M J$ 1986; 292: 1559-60

24 Kjellstrom T. Mechanism and epidemiology of bone effects cadmium. IARC Sci Publ 1992; 118: 301-10

25 Chambers RC, McNaulty RJ, Shock A, Campa JS, Newman Taylor AJ, Laurent GJ. Cadmium selectively inhibits fibroblast procollagen production and proliferation. Am J Physiol 1994; 267: L300-08

26 Toffoletto F, Apostoli P, Ghezzi I, Baj A, Cortona $\mathrm{G}$, Rizzi I, et al. Ten year follow up of biological monitoring of cadmium-exposed workers. IARC Sci Publ 1992; 118: 107-11

27 Roels H, Bernard AM, Cardenas A, Buchet JP, Lauwerys R, Hotter G, et al. Markers of early renal changes induced by industrial chemicals, III.
Application to workers exposed to cadmium. $\mathrm{Br} J$ Ind Med 1993; 50: 37-48

28 Lauwerys RR, Bernard AM, Roels HA, Buchet JP. Cadmium markers as predictors of nephrotoxic effects. Clin Chem 1994; 40: 1391-4

29 Bernard A, Roels H, Buchet JP, Cardenas A, Lauwerys R. Cadmium and health: the Belgian experience. IARC Sci Publ 1992; 118: 15-33

30 Davison AG, Newman Taylor AJ, Darbishire J, Chettle DR, Guthrie CJ, O'Malley D, et al. Cadmium fume inhalation and emphysema. Lancet 1988; i: $663-7$

31 Carruthers MM, Smith B. Evidence of cadmium toxicity in a population living in a zinc-mining area. Pilot survey of Shipham residents. Lancet 1979; i: $845-7$

32 Lemen RA, Lee JS, Wagoner JK, Blejer HP. Cancer mortality among cadmium production workers. Ann NY Acad Sci 1976; 271: 274-9

33 Armstrong BG, Kazantzis G. The mortality of cadmium workers. Lancet 1983 ; i: $1425-7$

34 Thun MJ, Schnorr TM, Smith AB, Halperin WE, Lemen RA. Mortality among a cohort of US cadmium production workers - an update. $J$ Natl Cancer Inst 1985; 75: 325-33

35 Kazantis G, Lam TH, Sullivan KR. Mortality of cadmium-exposed workers. A five-year update. Scand J Work Environ Health 1988; 14: 220-3

36 Kazantsis G, Blanks RG, Sullivan KR. Is cadmium a human carcinogen? IARC Sci Rep 1992; 118: 435-46

37 Beevers DG, Campbell BC, Goldberg A, Moore MR, Hawthorne VM. Blood cadmium in hypertensives and normotensives. Lancet 1976; ii: $1222-4$

38 Staessen R, Bernard A, Buchet JP, Claeys F, Dekempeneer L, Ducoffre G, et al. Effects of cadmium exposure on the cardiovascular system and on calcium metabolism: results of a crosssectional populations study. IARC Sci Publ 1992; 118: 263-9

39 Braithwaite RA, Armstrong R, Franklin DM, Chettle DR, Scott MC. Cadmium toxicokinetics following long term occupational exposure. In: Aitio A, Aro A, Jarvisalo J, Vaino H, eds. Proceedings of the Joint International Symposium of the Nordic Trace Element Society and the International Union of Pure and Applied Chemistry: Trace Elements in Health and Disease. Espoo, Finland 5-8 June 1990. Cambridge: Royal Society of Chemistry, 1991: 95-103

40 Sartor F, Rondia D, Claeys F, Buchet JP, Ducoffre $\mathrm{G}$, Lauwerys $\mathrm{R}$, et al. Factors affecting the cadmium body burden in a population study. IARC Sci Publ 1992; 118: 101-6

41 Gompertz D, Chettle DR, Fletcher JG, Mason H, Perkins J, Scott MC, et al. Renal dysfunction in cadmium smelters: relation to in-vivo liver and kidney cadmium concentrations. Lancet 1983; i: 1185-7

42 Roels H, Lauwerys R, Buchet JP, Bernard A, Chettle DR, Al-Haddad IK. In vivo measurement of liver and kidney cadmium in workers exposed to this metal. Environ Res 1981; 26: 217-40 
43 Donaldson MD, Chambers RT, Woolridge MW, Whicher JT. Stability of alpha-1-microglobulin, beta-2-microglobulin and retinol binding protein in urine. Clin Chim Acta 1989; 179: 73-8

44 Schaller KH, Angerer JH. Biological monitoring in the occupational setting - relation to cadmium exposure. IARC Sci Rep 1992; 118: 53-64

45 Jung K, Pergande M, Graubaum HJ, Fels LM, Endl U, Stolte H. Urinary proteins and enzymes as early indicators of renal dysfunction in chronic exposure to cadmium. Clin Chem 1993; 39: 757-65

46 Mueller PW. Detecting the effects of cadmium toxicity [editorial; comment]. Clin Chem 1993; 39: $743-5$

47 Bernard A, Roels H, Thielemans N, Van-Lierde M, Lauwerys R. Assessment of the causality of the cadmium protein relationships in the urine of the general population with reference to the Cadmibel study. IARC Sci Publ 1992; 118: 341-6

48 Health and Safety Executive. Cadmium: Health and Safety Precautions: Guidance Note EH 1. London: HMSO, 1986

49 Eybl V, Kotyzova D, Koutensky J, Jones MM, Singh PK. Effect of chelators, monoisoamyl meso2,3-dimercaptosuccinate and $\mathrm{N}$-(4-methylbenzyl)4-O-(beta-D-galactopyranosyl)-D-glucamine-N-carbodithioate on cadmium and essential element levels in mice. Analyst 1995; 120: 855-7

50 Major RH. Some landmarks in the history of lead poisoning. Ann Med Hist 1931; 3: 218-27

51 Franklin B. The pernicious effects of lead. In: Franklin B, ed. The Works of Ben Franklin. Philadelphia: BC Buzby, 1818

52 Grandjean P. International perspectives of lead exposure and lead toxicity. Neurotoxicology 1993; 14: 7-14

53 Fell GS. Lead toxicity: problems of definition and laboratory evaluation. Ann Clin Biochem 1984; 21: 453-60

54 Goyer RA. Lead toxicity: current concerns. Env Health Perspect 1993; 100: 177-87

55 Coyle P, Haywood MR, Rofe AM. Living with lead. An Australian overview. Clin Biochem Revs 1994; 15: 179-87

56 Matte TD, Proops D, Palazuelos E, Graef J, Avila HA. Acute high-dose lead exposure from beverage contaminated by traditional Mexican pottery. Lancet 1994; 344: 1064-5

57 Bayly GR, Braithwaite RA, Sheehan TMT, Dyer NH, Grimley C, Ferner RE. Lead poisoning from Asian traditional remedies in the West Midlands report of a series of five cases. Hum Experiment Toxicol 1995; 14: 24-8

58 Needleman HL, Gunnoe C, Leviton A, Reed R, Peresie H, Maher C, et al. Deficits in psychological and classroom performance in children with elevated dentine lead levels. N Engl J Med 1979; 300: 689-95

59 Needleman HL, Schell A, Bellinger D. The longterm effects of exposure to low doses of lead in children: an 11 year follow up report. $N$ Engl J Med 1990; 322: 83-8
60 Delves HT, Clayton BE, Carmichael A. An appraisal of the analytical significance of tooth lead measurements as possible indices of environmental exposure of children to lead. Ann Clin Biochem 1982; 19: 329-37

61 Hatzakis A, Kokkevi A, Maravelias C, Katsouyanni K, Salaminios F, Kalandidi A, et al. Psychomotor intelligence deficits in lead-exposed children. In: Smith MA, Green LD, Sors A, eds. Lead Exposure and Child Development. London: Kluwer, 1989: 211-23

62 Baghurst PA, McMichael AJ, Wigg NR, Vimpani GV, Robertson EF, Roberts RJ, et al. Environmental exposure to lead and children's intelligence at the age of seven years; the Port Pirie cohort study. N Engl J Med 1992; 327: 1279-84

63 Harvey PG, Hamlin MW, Kumar R, Morgan G, Spurgeon A, Delves HT. Relationship between blood lead, behaviour, psychometric and neuropsychological test performance in young children. Brit J Dev Psychol 1988; 6: 145-56

64 Fulton M, Raab G, Thomson G, Laxen D, Hunter $\mathrm{R}$, Hepburn W. Influence of blood lead on the ability and attainment of children in Edinburgh. Lancet 1987; i: $1221-6$

65 Pocock SJ, Smith M, Baghurst P. Environmental lead and children's intelligence: a systematic review of the epidemiological evidence. BMJ 1994; 309: 1189-97

66 Palca J. Lead researcher confronts accusers in public hearing. Science 1992; 256: 437-8

67 CDC Strategic Plan for the Elimination of Childhood Lead Poisoning. Atlanta: Centers for Disease Control Departments of Health and Human Services, 1991

68 Diermeyer M, Hedberg K, Fleming D. Backing off universal childhood lead screening in the USA: opportunity or pitfall? [commentary]. Lancet 1994; 344: $1587-8$

69 Department of the Environment. European Community Screening Programme for Lead: United Kingdom Results for 1981. Pollution Report No 18. London: HMSO, 1984

70 Department of the Environment. UK Blood Lead Monitoring Programme 1984-1987: Results for 1987. Pollution Report No 28. London: HMSO, 1990

71 Environmental Data Services Ltd, London. ENDS Report 1997 (269, June)

72 Millborne E, Russell J. Britain must replace its lead pipes to meet WHO standards for drinking water [letter]. BMJ 1995; 310: 1408-9

73 Church HJ, Day P, Braithwaite RA, Brown SS. Binding of lead to a metallothionein-like protein in human erythrocytes. J Inorg Biochem 1993; 49: 55-68

74 Barltrop D, Smith AM. Kinetics of lead interactions with human erythrocytes. Postgrad Med J 1985; 51: 770-3

75 Rossi E, Costin KA, Garcia-Webb P. Effect of occupational lead exposure on lymphocyte enzymes involved in haem biosynthesis. Clin Chem 1990; 36: 1980-3

76 Labbe RF. Lead poisoning mechanisms [editorial]. Clin Chem 1990; 36: 1870-1 
77 Pagliuca A, Baldwin D, Lestas AN, Wallis RM, Bellingham AJ, Mufti GJ. Lead poisoning: clinical biochemical and haematological aspects of a recent outbreak. J Clin Pathol 1990; 43: 277-81

78 Lee WR. What happens in lead poisoning? J Roy Coll Phys 1981; 15: 48-54

79 Cardenas A, Roels H, Bernard AM, Barbon R, Buchet JP, Lauwerys RR, et al. Markers of early renal changes induced by industrial pollutants. II Application to workers exposed to lead. $\mathrm{Br} J$ Ind Med 1993; 50: 28-36

80 Chisholm JJ Jr. Lead poisoning. Sci Am 1971; 224: $15-23$

81 Graham JA, Maxton DG, Twort CH. Painter's palsy: a difficult case of lead poisoning. Lancet 1981; ii: 1159-61

82 Chisholm JJ Jr. Mobilisation of lead by calcium disodium edetate: a reappraisal. Am $J$ Dis Child 1987; 141: 1256-7

83 Berger OG, Gregg DJ, Succop PA. Using unstimulated urinary lead excretion to assess the need for chelation in the treatment of lead poisoning. $J$ Paediatr 1990; 116: 46-51

84 Piomelli S, Rosen JF, Chisholm JJ, Graef JW. Management of childhood lead poisoning. Paediatrics 1984; 105: 523-32

85 Braithwaite RA, Sheehan TM, Davies RC. Blood lead analysis: beware of contaminated collection tubes. Association of Clinical Biochemists News Sheet 1991 (344, December): 26-7

86 Crick J, Flegal AR. Contaminant lead in bloodcollection tubes for trace element studies. Clin Chem 1991; 38: 600-1

87 Taylor A. The use of internal quality control materials for the preparation and maintenance of reliable methods for the measurement of lead in blood. Fresenius $Z$ Anal Chem 1988; 332: 732-5

88 Bullock DG, Smith NJ, Whitehead TP. External quality assessment of assays of lead in blood. Clin Chem 1986; 32: 1884-9

89 Delves HT. Analytical techniques for blood lead measurement. J Anal Toxicol 1977; 1: 262-4

90 Taylor A, Majumdar G, Delves HT. Probable self-administration of lead [letter]. Lancet 1985; i: 513

91 Taylor A. Usefulness of measurements of trace elements in hair. Ann Clin Biochem 1986; 23: 364-78

92 Campbell MJ, Delves HT. Accurate and precise determination of lead isotope ratios in clinical and environmental samples using inductively coupled plasma source mass spectrometry. J Anal Atom Spectrom 1989; 4: 235-6

93 Keen RW, Deacon AC, Delves HT, Moreton JA, Frost PG. Indian herbal remedies for diabetes as a cause of lead poisoning. Postgrad Med J 1994; 70: $113-4$

94 Piomelli S, Bernard D, Guinee VF, Young P, Gay G. The FEP free erythrocyte porphyrin test: a simple sensitive screening test for lead poisoning. Clin Chem 1972; 50: 254-9

95 Zwennis WCM, Franssen AC, Wijnans M. Use of zinc protoporphyrin in screening individuals for exposure to lead. Clin Chem 1990; 36: 1456-9
96 Parsons PJ, Reilly AA, Hussain A. Observational study of erythrocyte protoporphyrin screening test for detecting low lead exposure in children: impact of lowering the blood lead action threshold. Clin Chem 1991; 37: 216-25

97 Hurst PL, Hughes PM. Poor correlation between erythrocytic 5-aminolaevulinic acid dehydratase activity and blood lead concentration [letter]. Clin Chem 1985; 31: 1244-5

98 Holden A. St Albans Poisoner: Life and Crimes of Graham Young. London: Black Swan (Transworld), 1995

99 Reed MD, Crawley J, Faro SN, Pieper SJ, Kurland LT. Thallotoxicosis: acute manifestations and sequelae. JAMA 1963; 183: 516-22

100 Insley BM, Grufferman S, Ayliffe A. Thallium poisoning in cocaine abusers. Am J Emerg Med 1986; 4: 545-8

101 Dolgner R, Brockhaus A, Ewers U, Wiegand H, Majewski F, Soddemann H. Repeated surveillance of exposure to thallium in a population living in the vicinity of a cement plant emitting dust containing thallium. Int Arch Occup Environ Health 1983; 52: 79-84

102 Moore D, House I, Dixon A. Thallium poisoning. Diagnosis may be elusive but alopecia is the clue. BMJ 1993; 306: 1527-9

103 Chandler HA, Archbold GPR, Gibson JM, O'Callaghan P, Marks JN, Pethybridge RJ. Excretion of a toxic dose of thallium. Clin Chem 1993; 36: 1506-9

104 Cavanagh JB. What have we learned from Graham Frederick Young? Reflections on the mechanisms of thallium neurotoxicity. Neuropathol Appl Neurobiol 1991; 17: 3-9

105 Martin-Gil J, Delibes de Castro G, ZapateroMagdaleno P, Sarabia-Herrero FJ. Preserving the ancients with vermilion [letter]. Lancet 1994; 344: 1776

106 O'Shea JG. The death of Paganini. J Roy Coll Phys 1988; 22: 104

107 Stephenson JBP. Pink disease [letter]. BMJ 1966; i: $1110-1$

108 Yeh T, Pildes RS, Firor HV, Szanto PB. Mercury poisoning from mercurochrome therapy of infected omphalocoele [letter]. Lancet 1978; i: 210

109 Laundy T, Adam AE, Kershaw JB, Rainford DJ. Deaths after peritoneal lavage with mercuric chloride solutions: case report and review of the literature. BMJ 1984; 289: 96-8

110 Peterson DE, Kanarek MS, Kuykendall MA, Diedrich JM, Anderson HA, Remington PL, et al. Fish consumption patterns and blood mercury levels in Wisconsin Chippewa Indians. Arch Environ Health 1994; 49: 53-8

111 Svensson BG, Nilsson A, Jonsson E, Schutz A, Akesson B, Hagmar L. Fish consumption and exposure to persistent organochlorine compounds, mercury, selenium and methylamines among Swedish fisherman. Scand J Work Environ Health 1995; 21: 96-105

112 Harada M. Minnamata disease: methyl mercury poisoning in Japan caused by environmental pollution. Crit Rev Toxicol 1995; 25: 1-24 
113 Palheta D, Taylor A. Mercury in environmental and biological samples from a gold mine in the Amazon region of Brazil. Sci Total Environ 1995; 168: $63-9$

114 Mant TG, Lewis JL, Mattoo TK, Rigden SP, Volans GN, House IM, et al. Mercury poisoning after disc battery ingestion. Hum Toxicol 1987; 6: 179-81

115 Kew J, Morris C, Aihie A, Fysh R, Jones S, Brooks D. Arsenic and mercury intoxication due to Indian ethnic remedies. $B M J$ 1993; 306: 506-7

116 Sheerin NS, Monk PN, Aslam M, Thurston H. Simultaneous exposure to lead, arsenic and mercury from Indian ethnic remedies. $\mathrm{Br} J \mathrm{Clin}$ Pract 1994; 48: 332-3

117 Lauwerys R, Bonnier C, Evrard P, Gennart JP, Bernard A. Prenatal and early postnatal intoxication by inorganic mercury resulting from the maternal use of mercury containing soap. Hum Toxicol 1987; 6: 253-6

118 Mucklow ES. Health hazard from mercury soaps. Lancet 1989; i: 448

119 Tunnessen WW Jr, McMahon KJ, Baser M. Acrodynia: exposure to mercury from fluorescent light bulbs. Paediatrics 1987; 79: 786-7

120 Wendroff AP. Domestic mercury pollution [letter]. Nature 1991; 347: 623

121 Friberg L. Inorganic Mercury. International Programme on Chemical Safety, Environmental Health Criteria 118. Geneva: World Health Organisation, 1991

122 Fowler BA. Mechanisms of kidney cell injury from metals. Environ Health Perspect 1992; 100: $57-63$

123 Clarkson TW. Mercury: major issues in environmental health. Environ Health Perspect 1992; 100: 31-8

124 Pendergrass JC, Haley BE, Vimy MJ, Winfield SA, Lorscheider FL. Mercury vapor inhalation inhibits binding of GTP to tubulin in rat brain: similarity to a molecular lesion in Alzheimer diseased brain. Neurotoxicology 1997; 18: 315-24

125 Gala-Gorchev H. Dietary intake, levels in food and estimated intake of lead, cadmium and mercury. Food Addit Contam 1993; 10: 115-28

126 Weiner JA, Nylander M. An estimation of the uptake of mercury from amalgam fillings based on urinary excretion of mercury in Swedish subjects. Sci Total Environ 1995; 168: 255-65

127 Barregard L, Sallsten G, Jarvholm B. People with high mercury uptake from their own dental amalgam fillings. Occup Environ Med 1995; 52: 124-8

128 Halbach S. Combined estimation of mercury species released from amalgam. $J$ Dent Res 1995; 74: 1103-9

129 Clausen J. Mercury and multiple sclerosis. Acta Neurol Scand 1993; 87: 461-4

130 Fung YK, Meade AG, Rack EP, Blotcky AJ. Brain mercury in neurodegenerative disorders. $J$ Toxicol Clin Toxicol 1997; 35: 49-54

131 Fung YK, Meade AG, Rack EP, Blotcky AJ, Claassen JP, Beatty MW, et al. Determination of blood mercury concentrations in Alzheimer's patients. J Toxicol Clin Toxicol 1995; 33: 243-7

132 Eley BM. The future of dental amalgam: a review of the literature. Part 6: possible harmful effects of mercury from dental amalgam. Br Dent J 1997; 182: 455-9

133 Henriksson E, Mattsson U, Hakansson J. Healing of lichenoid reactions following removal of amalgam. A clinical follow-up. J Clin Periodontol 1995; 22: 287-94

134 Kanerva L, Komulainen M, Estlander T, Jolanki R. Occupational allergic contact dermatitis from mercury. Contact Dermatitis 1993; 28: 26-8

135 Handley J, Todd J, Burrows D. Mercury allergy in a contact dermatitis clinic in Northern Ireland. Contact Dermatitis 1993; 29: 258-61

136 Echeverria D, Heyer NJ, Martin MD, Naleway CA, Woods JS, Bittner AC. Behavioural effects of low-level exposure to elemental mercury among dentists. Neurotoxicol Teratol 1995; 17: $161-8$

137 Gallagher JD, Noelle RJ, McCann FV. Mercury suppression of a potassium current in human B lymphocytes. Cell Signal 1995; 7: 31-8

138 Goodwin CA, Wheeler-Jones CP, Namiranian S, Bokkala S, Kakkar VV, Authi KS, et al. Increased expression of procoagulant activity on the surface of human platelets exposed to heavy metal compounds. Biochem J 1995; 308: 15-21

139 Franchi E, Loprieno G, Ballardin M, Petrozzi L, Migliore L. Cytogenetic monitoring of fishermen with environmental mercury exposure. Mutat Res 1994; 320: 23-9

140 Jansson G, Harms-Ringhdahl M. Stimulating effects of mercuric and silver ions on the superoxide anion production in human polymorphonuclear lymphocytes. Free Radic Res Commun 1993; 18: 87-98

141 Herrstrom P, Holmen A, Karlsson A, Raihle G, Schutz A, Hogstedt B. Immune factors, dental amalgam and low dose exposure to mercury in Swedish adolescents. Arch Environ Health 1994; 49: $160-4$

142 Levin M, Jacobs J, Polos PG. Acute mercury poisoning and mercurial pneumonitis from gold ore purification. Chest 1988; 94: 554-6

143 Waldron HA. Did the Mad Hatter have mercury poisoning? BMJ 1983; 287: 1961

144 Buxton JT, Hewitt JC, Gadsden R, Bradham GB. Metallic mercury embolism. Report of cases. JAMA 1965; 193: 573-5

145 Auer C, Ducrey N, Uffer S, Othenin-Girard P, Herbot CP. Self-mutilating intraocular injection of metallic mercury. Arch Ophthalmol 1997; 115: 556-7

146 Giombetti RJ, Rosen DH, Kuczmierczyk AR. Repeated suicide attempts by the intravenous injection of elemental mercury. Int J Psychiatry Med 1988; 18: 153-67

147 Wright N, Yeoman WB, Carter GF. Massive oral ingestion of elemental mercury without poisoning [letter]. Lancet 1980; i: 206

148 Henningsson $\mathrm{C}$, Hoffman S, McGonigle L, Winter JSD. Acute mercury poisoning 
(acrodynia) mimicking phaeochromocytoma in an adolescent. J Paediatric 1993; 122: 252-3

149 McNeil NJ, Issler HC, Olver RE, Wrong OM. Domestic metallic mercury poisoning. Lancet 1984; i: 269-71

150 Campbell JR, Clarkson TW, Omar MD. The therapeutic use of 2,3-dimercaptopropane-1-sulphonate in two cases of mercury poisoning. JAMA 1986; 256: 3217-30

151 Toet AE, van Dijk A, Savelkoul TJ, Meulenbelt J. Mercury kinetics in a case of severe mercuric chloride poisoning treated with dimercapto-1propane sulphonate. Hum Exp Toxicol 1994; 13: 11-6

152 Shibata A, Ohneseit PF, Tsai YC, Spruck CH, Nichols PW, Chiang HS, et al. Mutational spectrum in the p53 gene in bladder tumours from the endemic area of blackfoot disease in Taiwan. Carcinogenesis 1994; 15: 1085-7

153 Chatterjee A, Das D, Mandal BK, Chowdhury TR, Samanta G, Chakraborti D. Arsenic in ground water in six districts of West Bengal, India: the biggest arsenic calamity in the World. Part 1. Arsenic species in drinking water and urine of affected people. Analyst 1995; 120: 643-50

154 Das D, Chatterjee A, Mandal BK, Samanta G, Chakraborti D, Chanda B. Arsenic in ground water in six districts of West Bengal, India: the biggest arsenic calamity in the World. Part 2 . Arsenic concentration in drinking water, hair, nails, urine, skin-scale and liver tissue (biopsy) of the affected people. Analyst 1995; 120: 917-24

155 Stoeppler M, Vahter M. Arsenic. In: Herber RFM, Stoeppler M, eds. Trace Element Analysis in Biological Specimens. Amsterdam: Elsevier, 1994: 291-320

156 Wilkinson SP, McHugh P, Horsley S, Tubbs H, Lewis M, Thould A, et al. Arsine toxicity aboard the Asiafreighter. BMJ 1975; 3: 559-63

157 Clarkson TW. Molecular targets of metal toxicity. In: Brown SS, Savory J, eds. Chemical Toxicology and Clinical Chemistry of Metals. London: Academic Press, 1983: 211-26

158 Lafontaine A. Health effects of arsenic. In: Di Ferrante E, ed. CEC Trace Metals: Exposure and Health Effects. Oxford: Pergamon Press, 1978: 107-16

159 Heaven R, Duncan M, Vukelja SJ. Arsenic intoxication presenting with macrocytosis and peripheral neuropathy, without anaemia. Acta Haematol 1994; 92: 142-3

160 Chen CJ, Kuo TL, Wu MM. Arsenic and cancers [letter]. Lancet 1988; i: 414-5

161 Le XC, Cullen WR, Reimer KJ. Human urinary arsenic excretion after one-time ingestion of seaweed, crab and shrimp. Clin Chem 1994; 40: 617-24

162 Vahter M. What are the chemical forms of arsenic in urine and what can they tell us about exposure? Clin Chem 1994; 40: 679-80

163 Koons RD, Peters CA. Axial distribution of arsenic in individual human hairs by solid sampling graphite furnace AAS. J Anal Toxicol 1994; 18: $36-40$
164 Moore DF, O'Callaghan CA, Berlyne G, Ogg CS, Davies HA, House IM, et al. Acute arsenic poisoning: absence of polyneuropathy after treatment with 2,3-dimercaptopropanesulphonate (DMPS). J Neurol Neurosurg Psychiatry 1994; 57 : 1133-5

165 Richardson BA. Sudden infant death syndrome: a possible primary cause. J Forensic Sci Soc 1994; 34: 199-204

166 Fleming PJ, Cooke M, Chantler SM, Golding J. Fire retardants, biocides, plasticisers and sudden infant deaths [editorial]. BMJ 1994; 309: 1594-6

167 Richardson BA. Cot mattresses and sudden infant death syndrome [letter]. Lancet 1995; 345 : 1045

168 Howatson AG, Patrick WJA, Fell GS, Lyon TDB, Gibson AAM. Cot mattresses and sudden infant death syndrome [letter]. Lancet 1995; 345: 1044-5

169 De-Wolff FA. Antimony and health [editorial]. BMJ 1995; 310: 1216-7

170 Warnock DW, Delves HT, Campbell CK, Croudace IW, Davey KG, Johnson M, et al. Toxic gas generation from plastic mattresses and sudden infant death syndrome. Lancet 1995; 346: 1516-20

171 Dezateux C, Delves HT, Stocks J, Wade A, Pilgrim L, Costeloe K. Urinary antimony in infancy. Arch Dis Child 1997; 76: 432-6

172 White GP, Mathias CG, Davin JS. Dermatitis in workers exposed to antimony in a smelting process. J Occup Med 1993; 35: 392-5

173 Thomas DW, Sobecki S, Hartley TF, Coyle P, Alp MH. Variable absorption and excretion of bismuth and its potential for toxicity. In: Brown SS, Savory J, eds. Chemical Toxicology and Clinical Chemistry of Metals. London: Academic Press, 1983: 391-4

174 Playford RJ, Matthews $\mathrm{CH}$, Campbell MJ, Delves HT, Hla KK, Hodgson HJ, et al. Bismuth induced encephalopathy caused by tripotassium dicitratobismuthate in a patient with chronic renal failure. Gut 1990; 31: 359-60

175 Kubulla J, Wilken RD, Jantzen E, Kwan KK, Chau YK. Speciation and genotoxicity of butyltin compounds. Analyst 1995; 120: 667-73

176 Walker AW, ed. Clinical and Analytical Handbook, 3rd edition. Guildford, UK: SAAS Trace Element Laboratories, 1998

177 Schramel P, Wendler I, Angerer J. The determination of metals (antimony, bismuth, lead, cadmium, mercury, palladium, platinum, tellurium, thallium, tin and tungsten) in urine samples by inductively coupled plasma-mass spectrometry. Int Arch Occup Health 1997; 69: 219-23

178 McElvaine MD, Harder EM, Johnson L, Baer RD, Satzger RD. Lead poisoning from the use of Indian folk medicines. JAMA 1990; 264: 2212-3

179 Sanchez-Guerrero J, Colditz GA, Karlson EW, Hunter DJ, Speizer FE, Liang MH. Silicone breast implants and the risk of connective-tissue diseases and symptoms. $N$ Engl J Med 1995; 332: 1666-70 
Appendix 1: Units in common use

Interpreting the range of units used for reporting results and reference ranges requires great care; the Control of Lead at Work Code of Practice (Control of Lead at Work; Code of Practice) expresses blood lead concentrations in $\mu \mathrm{g} / \mathrm{dL}$; toxicologists frequently use mass units, clinical scientists use $\mu \mathrm{mol} / \mathrm{L}$ and the Ministry of Agriculture, Fisheries and Food and the Water
Authorities use parts per million and billion. For biological monitoring of occupationally exposed subjects, $24 \mathrm{~h}$ urine collections are not practicable and random urine samples are used. The results are often expressed in terms of creatinine (unless this is extremely low) to compensate for dilution effects. Table 13 shows how the commonest units may be interconverted or approximated.

TABLE 13. Interconversion of units most frequently used

\begin{tabular}{lll}
\hline From & To & Calculation \\
\hline $\mathrm{ng} / \mathrm{L}$ & $\mathrm{nmol} / \mathrm{L}$ & Divide by atomic weight \\
$\mu \mathrm{g} / \mathrm{L}$ & $\mu \mathrm{mol} / \mathrm{L}$ & Divide by atomic weight \\
$\mu \mathrm{g} / \mathrm{dL}$ or $\mu \mathrm{g} / 100 \mathrm{~mL}$ & $\mu \mathrm{mol} / \mathrm{L}$ & Multiply by 10, divide by atomic weight \\
$\mathrm{ppm}$ & $\mathrm{mg} / \mathrm{L}$ & Equivalent \\
$\mathrm{ppm}$ & $\mu \mathrm{g} / \mathrm{mL}$ & Equivalent \\
$\mathrm{ppm}$ & $\mu \mathrm{g} / \mathrm{L}$ & Multiply by 1000 \\
$\mu \mathrm{g} / \mathrm{L}^{*}$ & $\mu \mathrm{mol} / \mathrm{mmol}$ creatinine & Divide by atomic weight, divide by 10 \\
$\mu \mathrm{g} / \mathrm{g}$ creatinine* & $\mu \mathrm{mol} / \mathrm{mmol}$ creatinine & Divide by atomic weight, divide by 10 \\
\hline
\end{tabular}

*Approximate conversions; normal creatinine concentration being assumed as $1 \mathrm{~g} / \mathrm{L}$, which is roughly equivalent to $10 \mu \mathrm{mol} / \mathrm{L}$. 